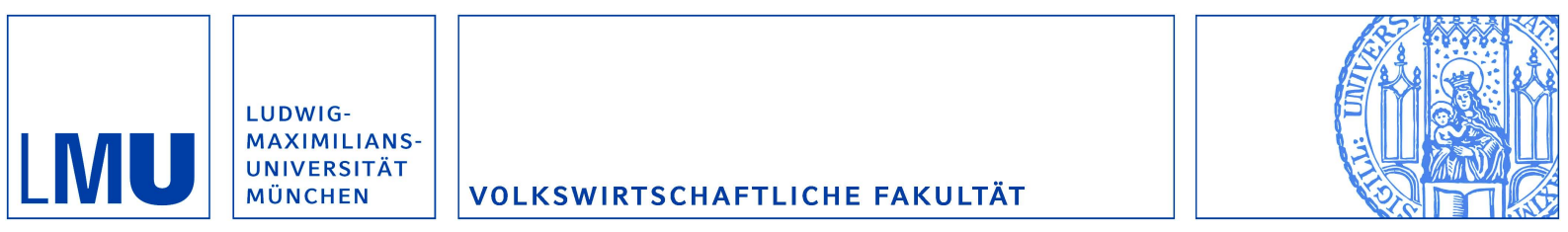

Lechler, Marie:

Employment Shocks and anti-EU Sentiment

Munich Discussion Paper No. 2018-5

Department of Economics

University of Munich

Volkswirtschaftliche Fakultät

Ludwig-Maximilians-Universität München

Online at https://doi.org/10.5282/ubm/epub.49414 


\title{
Employment Shocks and anti-EU Sentiment
}

\author{
Marie Lechler* \\ Department of Economics, University of Munich (LMU)
}

\begin{abstract}
Euroscepticism and the rise of populist parties have often been linked to economic insecurity. This paper identifies regional employment changes as causal factors for forming attitudes towards the European Union and voting for eurosceptic parties in European Parliament elections. To do so, I combine industry-specific employment data for roughly 260 European NUTS II regions with individual-level Eurobarometer survey data for the past 20 years and regional voting results. I apply panel data and instrumental variable methods; for the latter I construct a Bartik-style instrument, which predicts employment changes on the basis of regional industry specialization and Europe-wide sector specific employment growth rates. The effect of employment changes on attitudes towards the EU is particularly strong for unemployed and low-skilled workers in regions with a high share of migrants from other European member states, which supports the narrative that 'losers of globalization' tend to be more skeptical towards economic and political integration.
\end{abstract}

JEL classification: E24, F66, F68, J21, O52, P16

Keywords: European Integration, Regional Employment, EU Attitudes, European Parliament Elections, EU Migration

${ }^{*}$ I would like to thank Davide Cantoni, Clemens Fuest, Elias Papaioannou, Gerard Roland, Jan Stuhler, Uwe Sunde, Mark Westcott and students and faculty at LMU Munich and University of California, Berkely for helpful comments and suggestions. 


\section{Introduction}

Populist parties in many European countries, such as UKIP in the UK, FN in France, PVV in the Netherlands or AfD in Germany have made electoral breakthroughs. Such parties espouse a nationalistic agenda and oppose globalization. This populism is often manifested as Euroscepticism, with populist parties and their supporters seeing the EU as an institutional symbol of globalization. These eurosceptic ideologies can be harmful as support for the EU is key for its legitimacy and effectiveness (Hobolt and de Vries, 2016), which in turn fosters political stability and economic prosperity (Schmidt, 2013). It is therefore important to better understand determinants of support for the EU. In the public debate, rising unemployment and the lack of economic perspectives are among the most frequently mentioned reasons for the success of these views. ${ }^{1}$ Even the President of the European Central Bank, Mario Draghi, has emphasized the importance of policies which aim at mitigating economic inequality and job insecurity in the EU to prevent the rise of populism. ${ }^{2}$

I contribute to this debate by showing that regional labor market conditions affect support for the EU. I document that regions experiencing negative employment changes tend to vote for more eurosceptic parties in European Parliament elections and also show a higher attitudinal euroscepticism. Support for the EU and euroscepticism are defined as two sides of the same coin encompassing attitudes toward the European Union as a regime and its principles. I focus my analysis on attitudinal euroscepticism because it is comparable across countries (as opposed to political parties) and captures the distinct nature of anti-EU attitudes, which is not the case with political parties that campaign on several platforms. In order to quantify attitudinal euroscepticism I analyze Eurobarometer survey data and combine them with regional employment data. The Eurobarometer questions ask about the respondents' image of the EU, the respondents' assessment of the benefits from the EU and the respondents' evaluation of their country's EU membership.

There are huge differences in these attitudes across regions but it is difficult to distinguish economic factors from other factors such as culture, regional institutions or local politics, which are correlated with both labor market conditions and attitudes. I therefore apply panel fixed effect estimation methods, which exploit variation within regions over time, thereby conditioning on region-specific and time-specific unobserved heterogeneity. I also include lagged dependent

\footnotetext{
1"Brexit is a rejection of globalisation" (Guardian, June 2016). "People who are left behind by structural change and so-called 'losers of globalization' are prone to the rhetoric of the AfD". In German: "vom Strukturwandel Abgehängte und sogenannte 'Globalisierungsverlierer' seien anfällig für die Rhetorik der AfD." (WirtschaftsWoche, February 2018). Angela Merkel in a governmental statement about Brexit: "We have to make Europe more competitive and close the gap between losers and winners of globalization". In German: "[wir müssen uns] gemeinsam dafür einsetzen, Europa wettbewerbsfähiger zu machen und die Kluft zwischen Globalisierungsgewinnern und Globalisierungsverlierern zu verkleinern." (Regierungserklärung Angela Merkel, June 2016).

"'In unusually political remarks, Mr Draghi called on Brussels to pay more attention to redistribution and address concerns- such as economic inequality and job insecurity- that have played into the hands of populist anti-European parties across the EU." in "Do more to help globalisation's losers, say champions of liberalism" (Financial Times, September 2016).
} 
variables in order to account for feedback effects from past attitudes on employment. Finally, I control for a number of factors that may be correlated with labor market conditions and support for the EU such as education, demography and migration.

Regional employment changes may nevertheless be still endogenous to attitudes due to third factors that are neither region-specific nor time-constant and are not captured by the control variables. To account for that I construct a Bartik-style shift-share instrument (Bartik, 1991) that predicts regional employment changes on the basis of Europe-wide sectoral employment growth and regional industrial specialization. ${ }^{3}$ This instrument provides plausibly exogenous variation in regional employment and allows me to identify a causal effect.

In all specifications I find a significantly positive effect of employment changes on support for the EU. This effect is driven by variation in negative employment changes rather than positive ones. In an attempt to identify a potential mechanism, I further analyze interaction effects with education, occupation and migration. The theoretical literature has suggested that nationalist ideology appeals in particular to 'modernization losers' (Golder, 2016; Garry and Tilley, 2009). Hence, those who are threatened to lose most from further European integration, such as unskilled people in regions with a lot of low-skilled EU migration, are most likely to be eurosceptic. Consistent with this, I find that both unemployed and low-skilled workers react particularly strongly to employment changes. Moreover, the triple interaction between employment changes, an unskilled worker dummy and EU migration is statistically significant. This finding indicates that unskilled are particularly sensitive to employment changes in regions with high shares of EU migration.

This paper contributes to the literature on several dimensions. First, I exploit variation across 260 European regions over a long time horizon (1996-2014) and am therefore able to control for region and time specific factors that may cause bias. Second, I analyze three different attitudinal dimensions of euroscepticism, which account for its 'multifaceted nature' (Boomgaarden et al., 2011). Other studies have often only focused on one aspect, for example trust in institutions. Moreover, I present results for voting behavior in European Parliament elections using administrative voting data rather than self-reported ones as in other studies (Guiso et al., 2017; Hernández and Kriesi, 2016). Third, I construct a Bartik-style instrument for European regions, which arguably extracts the exogenous component in employment changes. This instrument has not been applied to the European context before. Fourth, I investigate potential mechanisms such as occupation and education as well as their interaction with regional migration.

There is a large literature emphasizing the link between economic insecurity and antiglobalization sentiment (see Anderson (2007) for an overview). A recent strand of literature examines effects of globalization, most notably trade shocks on political polarization and extreme voting. Autor et al. (2016) find that US districts exposed to high import competition tend to remove moderate representatives from office. They conclude that "employment conse-

\footnotetext{
${ }^{3}$ For applications see also Blanchard and Katz (1992), Katz and Murphy (1992), Bound and Holzer (2000) and Autor et al. (2016).
} 
quences of trade [are] acutely recognizable and therefore politically actionable" (p.45). Similarly, Che et al. (2016) show that US counties exposed to import competition from China experience increases in turnout and are more likely to be represented by a Democrat. Colantone and Stanig (2018) examine the effects of import competition on western Europe and also find that import shocks lead to an increase in support for nationalist parties and a general shift to the right in the electorate. Dippel et al. (2015) present causal evidence for the effect of trade integration on extreme right voting for Germany. All of these studies apply an instrumental variable strategy exploiting variation in import penetration from China depending on the local industry structure, which is advanced in Autor et al. (2013). Guiso et al. (2017), Algan et al. (2017) and Dustmann et al. (2017) provide evidence that economic factors are important determinants of support for right-wing populist parties in Europe.

Right-wing voting is often associated with nationalist ideologies. Therefore another strand of literature focuses on the effects of economic conditions on attitudes measured in surveys. Hobolt and de Vries (2016) provide an extensive overview over the literature about origins of public support for European integration and its consequences. Roth et al. (2013), Frieden (2016), Dustmann et al. (2017) and Algan et al. (2017) document a decline in trust in European and national institutions as a consequence of the financial crisis. Roth et al. (2013) show that the economic crisis of 2008-2012 had a particularly pronounced negative effect on trust in the European Commission and European Parliament in the four periphery countries (Spain, Greece, Portugal and Ireland). Dustmann et al. (2017) and Algan et al. (2017) confirm that the economic crisis reduced trust in national and European institutions and was associated with the rise of anti-establishment parties. In terms of labor market conditions Dustmann et al. (2017) find for the EU15 that the unemployment rate has a negative- albeit not significant- effect on support for European integration and a negatively significant effect on trust in the European Parliament and on the vote share of pro-EU parties. Algan et al. (2017) present evidence that underpins these results. Increases in unemployment are associated with voting for non-mainstream parties and a decline in trust in national and European institutions. In order to causally identify this effect they use the share of pre-crisis construction as instrument for employment changes during the economic crisis. The Bartik-style instrument applied in this paper however goes beyond their instrument as it uses both variation across sectors and over time rather than only variation across regions.

All these studies focus on trust in institutions as main attitudinal outcomes. My analysis complements this by focusing on the image of the EU, the perceived benefit from the EU and the evaluation of EU membership in general and thereby disentangles the effect of labor market conditions on mistrust in institutions and euroscepticism. There are a few studies which analyze the effect of economic conditions on this 'attitudinal euroscepticism' ${ }^{4}$ Both Serricchio et al. (2013)

\footnotetext{
${ }^{4}$ Other papers have studied macroeconomic and socioeconomic determinants of euroscepticism. The following factors are particularly important in determining euroscepticism: inequality (Kuhn et al., 2016), regional transfers from EU structural funds (Osterloh, 2011), social class (Lucassen and Lubbers, 2012), perceived threat from immigrants (Lucassen and Lubbers, 2012; Lubbers and Scheepers, 2007; De Master and Le Roy, 2000), education (Lubbers and Scheepers, 2010), age (Down and Wilson, 2013).
} 
and Gomez (2015) establish a link between the financial crisis and euroscepticism measured with the Eurobarometer membership question. While Gomez (2015) finds a strong effect of economic variables such as GDP growth, unemployment rate and interest rates on support for the EU in the context of the financial crisis, Serricchio et al. (2013) conclude that economic indicators have very limited power in explaining euroscepticism. They instead attribute the effect of the financial crisis to national identity and political institutions. Both approaches however have analytical shortcomings. Their time frame is rather short (2007-2011 in Gomez (2015) and only 2007 and 2010 in Serricchio et al. (2013)) and the unit of analysis is the country-level. Lubbers and Scheepers (2010) examine the evolution of euroscepticism for the pre-crisis period (1994-2004) and find that changes in economic growth, inflation and unemployment are hardly related to euroscepticism. Their analysis is also conducted on a country level. A regional-level analysis over a long time span examining the effect of labor market conditions on different aspects of 'attitudinal euroscepticism' is still missing from the literature.

The paper is structured as follows: I first describe the political attitude, voting, and regional employment data (Section 2). I then discuss both the fixed effect and the instrumental variable estimation strategies (Section 3). The main analysis is conducted in Section 4 measuring euroscepticism with survey data. I present results from the panel analysis including effect heterogeneity and also from instrumental variable estimations. Finally, I present results about the relationship between labor market conditions and voting behavior in European Parliament elections in Section 5.

\section{Data}

The dataset is a panel containing political attitude, voting and employment information for 265 European NUTS II regions in 25 countries between 1994 and $2014 .^{5}$ Data for new member states is available since $2004 .{ }^{6}$ European Parliament election data is available for the years 1994 (EU12), 1999 (EU15), 2004 (EU25), 2009 (EU25) and 2014 (EU28).

\subsection{Political Attitude Data: Eurobarometer}

Analyzing attitudes toward the European Union is important because they ultimately affect voting decisions as voting is a form of revealing preferences. While it is hard to disentangle dissatisfaction with EU from other reasons why people vote for right-wing, populist parties (e.g. dissatisfaction with national governments) survey evidence is able to pinpoint the anti-European nature of dissatisfaction. The main part of the analysis in this paper will therefore focus on the

\footnotetext{
${ }^{5}$ Austria, Belgium, Bulgaria, Czech Republic, Denmark, Estonia, Finaland, France, Germany, Great Britain, Greece, Hungary, Italy, Ireland, Latvia, Lithuania, Luxembourg, Netherlands, Poland, Portugal, Romania, Slovakia, Slovenia, Spain, Sweden.

${ }^{6}$ Estonia, Latvia, Lithuania, Poland, Czech Republic, Slovakia, Hungary, Slovenia.
} 
determinants of satisfaction with the EU measured with survey responses. It is reassuring that anti-EU voting and attitudinal euroscepticism measured with survey questions are correlated with correlation coefficients around 0.4 (Appendix Table A5).

In order to measure political attitudes I use the Euobarometer survey (European Commission, $2017)^{7}$, which asks 1000 representative respondents per EU member country twice a year about their opinion on various EU related topics. ${ }^{8}$ The measures for respondents' attitudes toward the EU ask whether the respondent thinks that his/her country has benefited from EU membership, whether his/her country's EU membership is a good or bad thing and whether the EU conjures up a positive or negative image (see exact wording of questions and summary statistics in Appendix Section A.7). Boomgaarden et al. (2011) emphasize that EU attitudes are of 'multifaceted nature' and therefore focusing on one aspect would fall short of a comprehensive characterization of euroscepticism. The membership questions has been widely used in previous literature (Frieden, 2016; Kuhn et al., 2016; Gomez, 2015; Osterloh, 2011; Lubbers and Scheepers, 2010). Lubbers and Scheepers (2005) classified the membership and benefit questions as 'instrumental euroscepticism' reflecting cost/benefit considerations. The image variable is characterized as 'evaluative' dimension of pro-/anti-European sentiment by Fernandez et al. (2016) and is less frequently used in the literature. One reason might be that it was only introduced to the Eurobarometer questionnaire in 2001. The questions are not all asked in each survey round. While the benefit and membership questions are available between 1994 and 2011, the image question was asked between 2001 and 2014. For the years 2001 to 2011 I combine information from all three variables using the first principal component and create a "EU Support Index". In order to use as much variation over time as possible the main specifications are estimated for each outcome variable separately. To make the dependent variables comparable all three are binarized. I also extract data on the evaluation of national institutions (trust in national government and trust in national parliament) from the survey as these constitute important control variables. These variables are also binarized as to make them comparable.

Eurobarometer also contains information about the region of residence (NUTS $\mathrm{II}^{9}$ ) of the respondent so that the data can be linked to other regional data. I aggregate the variables to annual intervals by averaging the values by region over all survey rounds that contain the respective survey question in that year. Finally, I standardize the variables to lie between 0 and 100, so that the values can be interpreted as $\%$ of people in a given region in a given year who have a positive image of the EU/ think that their country benefits from EU membership/ believe that their country's EU membership is a good thing. Figure 1 displays the distribution of support for the EU as measured by the image variable and averaged over the years 2010-2014 across Eu-

\footnotetext{
${ }^{7}$ Eurobarometer thus provides much more frequent data covering a longer time span than the European Social Survey (ESS), which is used in many other studies (Dustmann et al., 2017; Algan et al., 2017). ESS is a bianual survey, which starts in 2002.

${ }^{8}$ PSUs are selected from each of the administrative NUTS II regions in every country so that each region is represented in the sample. "PSU selection was systematic with probability proportional to population size, from sampling frames stratified by the degree of urbanization" (Eurobarometer, 2017).

${ }^{9}$ For Germany and UK only NUTS I level available from 2004 onwards.
} 
Figure 1: Distribution of image of EU across NUTS II regions

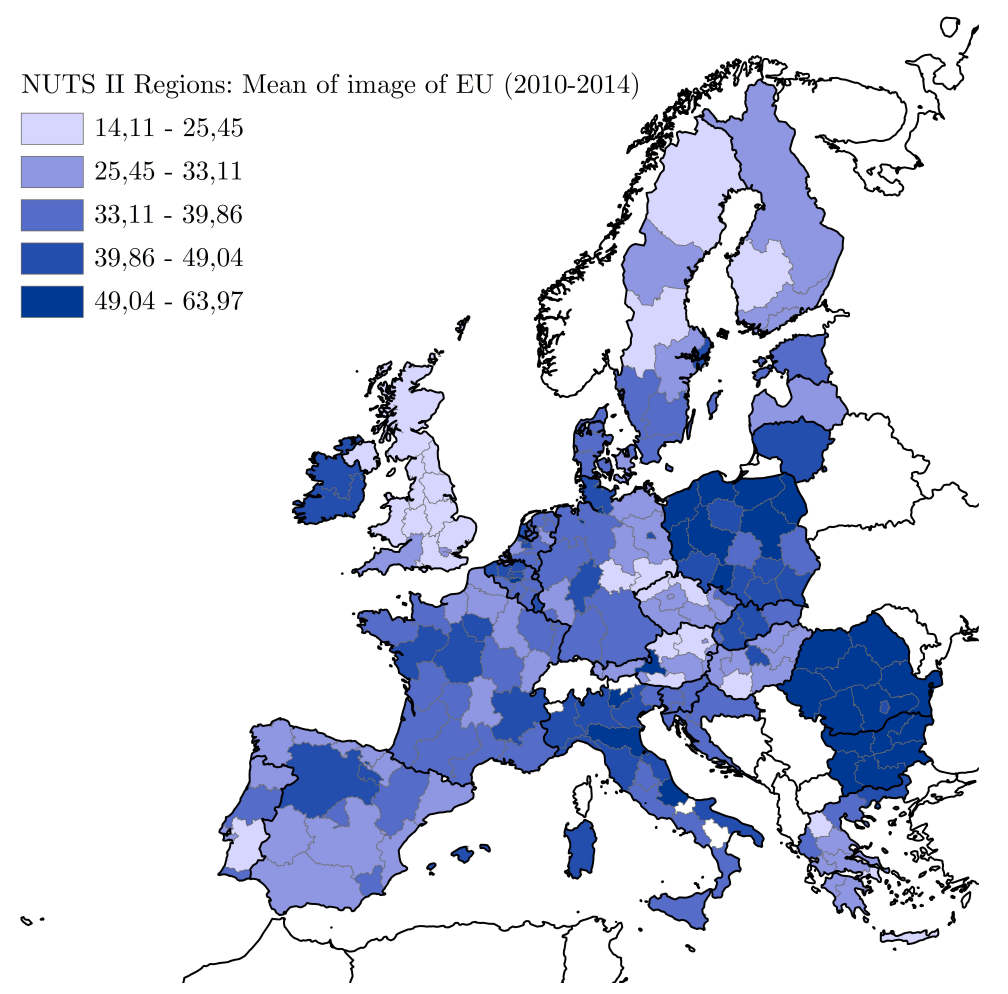

ropean regions. Figure A1 in the Appendix illustrates the evolution of attitudes toward the EU over time. Summary statistics of the regional-level characteristics are provided in the Appendix Table A1.

The survey also asks about individual characteristics such as age, gender and education, which are important determinants of political attitudes and thus important control variables and possibly interesting interacting factors. I therefore also estimate a model using all individual level observations rather than the region aggregates. Summary statistics of the individual-level variables can be found in the Appendix Table A2.

\subsection{Voting Data}

The voting data for the years 1994-2009 stem from the European Election Database (EED), which contains voting data on a regional level (NUTS II) for European Parliament Elections for the years 1994, 1996 (Austria and Finland), 1999 (EU15), 2004 (EU25), 2007 (Bulgaria and Romania) and 2009 (EU27). I added missing data based on national databases. ${ }^{10}$ For the 2014 EP election I collected data for all $28 \mathrm{EU}$ member states based on national databases (see Appendix Table A3 for sources). In order to identify pro-EU parties I use results from the Euromanifesto Study, which allocates each party a score on a pro/anti- EU scale based on content

\footnotetext{
${ }^{10}$ I compiled regional voting data for the following countries: Poland, Portugal, and UK.
} 
analysis of party programs ('Pro EU Score'). ${ }^{11}$ This pro-/anti-EU score is highly correlated (0.73) with expert evaluations of parties' position toward European integration (Chapel Hill Expert Survey, Bakker et al. (2015)). I then multiply each party's pro-EU score with the vote share that this party gained in region i in election year t. As I cannot allocate scores to each party (Euromanifesto only coded 'relevant' parties) the vote shares do not sum up to 1. I therefore weight the final measure with the inverse of the total vote share of all parties that are coded in region $\mathrm{i}$ in year $\mathrm{t}$.

$$
\text { Pro EU Vote } \text { Score }_{i t}=\sum_{p} \text { Pro EU Score } \text { Prt }^{*} \text { Vote }_{\text {Share }} \text { pit }^{*} \frac{1}{\sum_{p} \text { Vote }_{\text {Share }} \text { pit }}
$$

This index ranges from -18 (anti-EU) to 24 (pro-EU) with a mean of 6.7 and is available for 234 regions in the $28 \mathrm{EU}$ countries. For ease of interpretation and to allow comparability with the other outcomes I standardize the variable to lie between 0 and 100. Figure 2 shows the distribution of pro-EU voting across Europe. The strongest anti-EU voting behavior was observed in the East Midlands, UK in 2004 (the strongly eurosceptic UKIP received $26 \%$ of the votes and the BNP 6.5\%). See summary statistics of the Pro EU Vote Score in Appendix Table A4.

\footnotetext{
${ }^{11}$ Euromanifesto evaluates quasi-sentences in party programs. "A classification scheme with invariant general categories is used to cover the total content of election programs by identifying the statements of preference expressed in the programs. [...] Thus, the coding procedure comprises a quantification (how many statements do parties make?) and a classification (what kind of statements do parties make?) of election programs" (Braun et al., 2015, p. 22). The 'Pro EU' variable represents the dimension pro versus contra European integration and is the sum of prointegration codes (16 variables) minus the sum of integration-sceptic codes (19 variables). It ranges from -100 (anti-EU) to 100 (pro-EU).
} 
Figure 2: Distribution of pro-EU voting across NUTS II regions in 2014 European Parliament elections

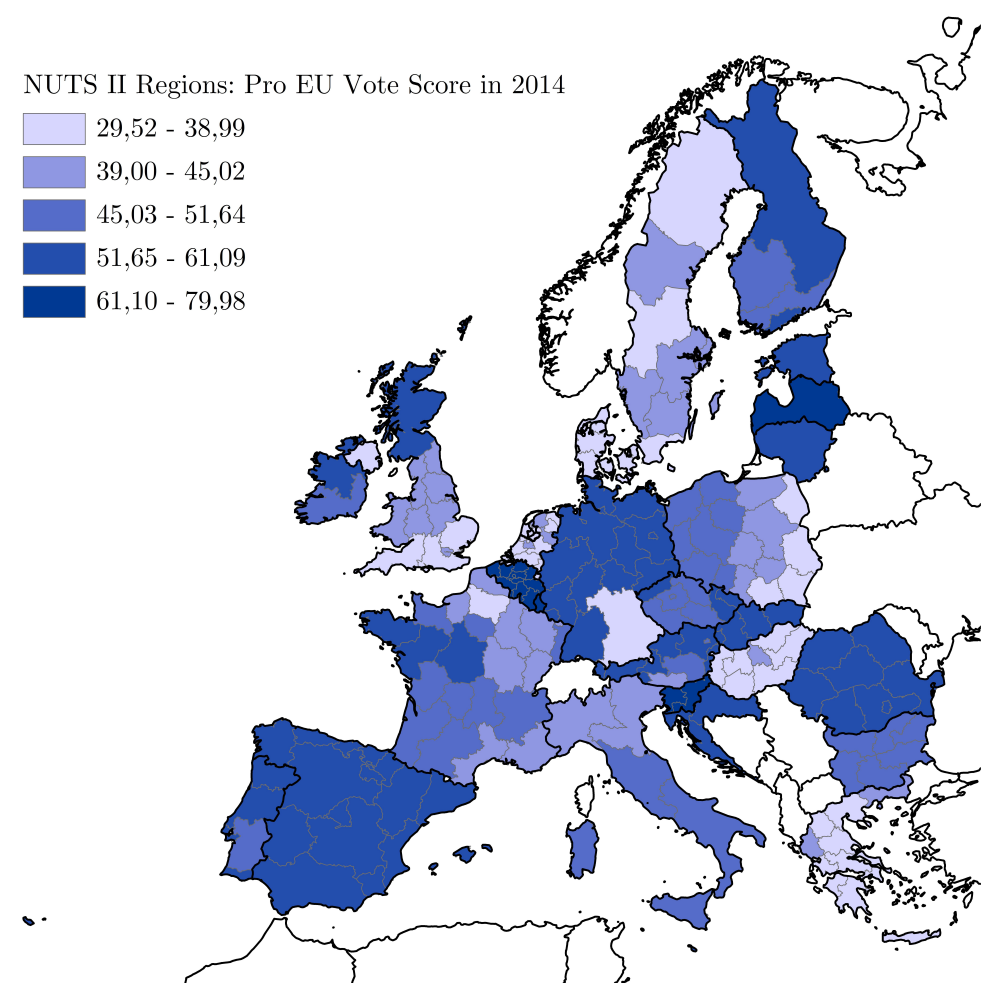

\subsection{Employment Data}

The employment data used in this study comes from Cambridge Econometrics, which combines regional and sectoral data from both Eurostat's REGIO database and AMECO, which is provided by the European Commission's Directorate General Economic and Financial Affairs. The disaggregated data is available for 286 NUTS II regions in 27 EU countries (all EU member states except Malta) and 6 sectors since $1990 .{ }^{12}$ The main variable of interest is employment, which "covers all persons engaged in some productive activity (within the production boundary of the national accounts)". As changes in employment may simply reflect changes in the working-age population I adjust this measure by dividing by the active population. ${ }^{13}$ The main explanatory variable in this study is the change of the employment rate in region i over the past five years. I expect the change of the employment rate to affect attitudes rather than levels as people are more likely to react to changes, which is confirmed by Algan et al. (2017) findings. The 5-year time horizon was chosen to capture variations that are not only driven by short-term events but represent significant changes in the labor market that people have noticed and can

\footnotetext{
${ }^{12} \mathrm{~A}$ (agriculture, forestry and fishing), B-E (industry), F (construction), G-J (wholesale, retail, transport, accommodation \& food services, information and communication), K-N (financial and business services) and $\mathrm{O}-\mathrm{U}$ (non-market services).

${ }^{13}$ The active population includes both employed and unemployed people, but not economically inactive, such as students and pensioners. Employment relative to active population can be greater than 1 in regions where many people work in a different region than they live, such as Brussels (BE10) or Luxembourg (LU00).
} 
still remember. Moreover it corresponds to the 5-year interval between European Parliament elections. I show that the effects do however not depend on the time horizon.

$$
\text { Change Employment Rate } \text { E }_{i t}=\frac{\frac{\text { Employment }_{i t}}{\text { Active Population }_{i t}}-\frac{\text { Employment }_{i t-5}}{\text { Active Population }_{i t-5}}}{\frac{\text { Employment }_{i t-5}}{\text { Active Population }} \text { it }-5} \cdot 100
$$

Employment changes for all region-year pairs are close to normally distributed (see Figure A2 in the Appendix) and its mean over the period 1994-2014 is slightly above zero. Both positive and negative outliers (smallest and highest 1\%) were excluded from the sample. The largest drop in employment occurred in Greece between 2008 and 2013 (-16\%) and the biggest increase occurred in Portugal between 1993 and $1998(+16 \%)$. Figure A3 in the Appendix illustrates the evolution of the change of the employment rate over time for different country sub-samples. Detailed summary statistics can be found in Appendix Table A6.

\subsection{Additional Data}

In addition I use migration data extracted from the EU Labor Force Survey (LFS), which provides information on regional employment, nationality and educational attainment of respondents. For the purposes of my analysis I distinguish between nationals of the reporting country, EU nationals and non-EU nationals. To identify low-skilled respondents I use the 3 step education measure (high, middle and low) based on the Intentional Standard Classification of Education (ISCED). These data is only available since 2006 for EU nationals (which is the most relevant group of migrants) and is therefore most suitably combined with the image outcome so that data for 9 overlapping years is available for analysis. Summary statistics are provided in Table A7 in the Appendix.

Finally, I use data on education (share of population between 15 and 65 with primary, secondary and tertiary education), median age and old-age ratio (above 65 year olds compared to 15-65 year olds) and net migration rate on NUTS II level from Eurostat. These data is available since 2000 .

\section{Empirical Strategy}

Figure 3 demonstrates that there is a clear positive relationship between changes in regional employment and support for the EU. It is however difficult to identify a causal effect of changes in employment on support for the EU as labor market conditions are not assigned randomly. To the contrary, labor market conditions are related to policies, political and economic institutions and crisis which may all be correlated with support for the EU at the same time. I therefore apply two different estimation strategies to tackle these problems. 
Figure 3: Employment changes and image of EU

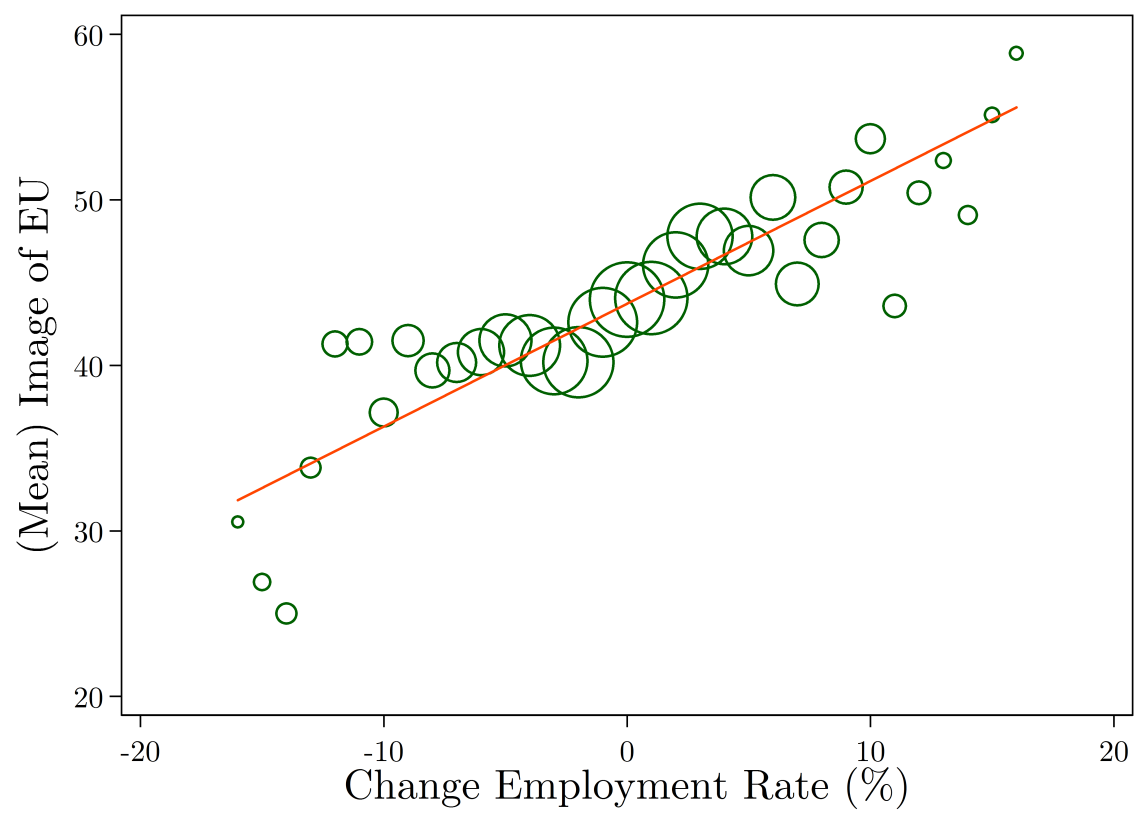

Change of employment rate (rounded to closest integer) and image of EU (averaged over each bin). Size of bubbles corresponds to number of region-year observations per bin.

First, I estimate a panel model including time and region fixed effects to account for all regionand time-specific factors. In the primary specification, I estimate the following model:

$$
\text { EU Support } i t=\alpha+\beta \Delta \text { Employment } \text { Rate }_{i \tau}+\mathbf{X}_{i t}^{\prime} \gamma+\mu_{t}+\delta_{i}+u_{i t}
$$

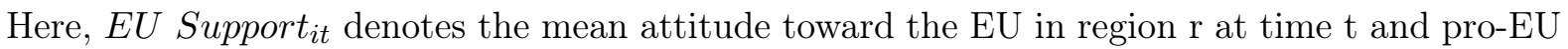
voting score in region i at time $t$ respectively. $\Delta$ Employment Rate ${ }_{i \tau}$ is the change of employment rate between $t$ and $t-5$ and $\beta$ is the main coefficient of interest. $\mathbf{X}_{i t}$ is a vector of control variables (level of employment rate, national institutions, migration, demography, education), which are successively included. $\mu_{t}$ are year fixed effects and $\delta_{i}$ are region fixed effects. The estimation is conducted by least squares and the error term $u_{i t}$ allows for clustering at the regional level. This model accounts for region-specific factors such as institutions, culture or experience with the EU, which are correlated with both labor market outcomes and attitudes toward the EU. The region-specific fixed effects also capture EU funding, which is targeted at less developed regions and hardly varies over time. ${ }^{14}$ Moreover, time fixed effects capture year-specific events that affect all European regions as for example the financial crisis. In an additional specification,

\footnotetext{
${ }^{14}$ The goal of EU transfers is to achieve equalization among European regions and the biggest part of all transfers is spent by the Structural Funds Programme (Becker et al., 2010). There are three funding periods covering the time span of my sample: 1994-1999, 2000-2006 and 2007-2013. Regions defined as "less developed" receive the vast majority of funds. These tend to be the same ones in all funding periods (http://ec.europa. eu/regional_policy/en/).
} 
I also control for country specific linear time trends, which capture country specific changes over time (for example years since a country joined the EU).

In order to rule out reversed causality issues, i.e. past attitudes affecting contemporary labor market conditions (for example through elected politicians) I control for the fifth time lag of the dependent variable. In order to account for potential Nickell bias (Nickell, 1981) I also present specifications using a bias corrected LSDV dynamic panel data estimator (Bruno, 2005).

As robustness check, I test the sensitivity of the results with respect to the definition of the explanatory variable. I use different time horizons for the change of the employment rate, I binarize the explanatory variable to only distinguish between negative and positive changes, I control for absolute employment changes and changes in active population separately and I also control for the level of the employment rate. In addition, I show a robustness check using the EU support index as dependent variable, which comprises all three dimensions of the other dependent variables. To rule out that the effect is driven by third variables such as general disappointment with politicians, education, demographic patterns or migration I control for these factors. They may however be considered 'bad' controls in the Angrist \& Pischke sense (Angrist and Pischke, 2008) as they are outcomes of the treatment themselves and are therefore not included in the main specifications.

I also explore potential mechanisms driving this effect. The literature has shown that cost/benefit considerations are important in forming an attitude about the European Union (Frieden, 2016; Foster and Frieden, 2017). I therefore expect people who fear to loose from further integration such as unemployed or low-skilled workers to be more sensitive toward employment changes than others. I analyze whether the effects are driven by positive or negative employment changes by splitting the sample. This helps to understand whether people distinguish between positive and negative labor market outcomes in attributing the changes to the EU. I also compare the labor market effects to migration effects and evaluate the interaction between the two. I then take advantage of the individual level data provided by Eurobarometer, which allows me to identify groups by employment status, age and education and their responsiveness to changes in employment.

Secondly, I apply an instrumental variable approach using a sector-specific Bartik (also known as shift-share) instrument (Bartik, 1991). It predicts regional employment changes on the basis of Europe-wide employment growth across industries and exploits the fact that regions differ in their industrial specialization, and that employment rises and falls unevenly across industries over time. The instrument is constructed in the following way:

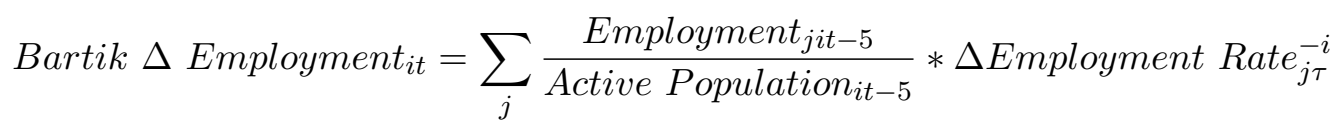

$\frac{\text { Employment }_{\text {jit }-5}}{\text { Active Population }_{\text {it }-5}}$ denotes the share of total employment in active population in industry $\mathrm{j}$ in 
region $\mathrm{i}$ in year $\mathrm{t}-5$. Using the fifth lag ensures that specialization patterns are not themselves the consequence of changes is certain industries. $\Delta$ Employment Rate $e_{j \tau}^{-i}$ is the change of the employment rate in industry $\mathrm{j}$ between $\mathrm{t}$ and $\mathrm{t}-5$ for all European regions (excluding region $\mathrm{i}$ ). The variation thus stems from different sectoral compositions across regions in combination with changes in Europe-wide industry conditions. As employment varies unevenly across industries and over time and regions differ in their industrial specialization, regions are differently exposed to Europe-wide industry shocks. These shocks are assumed to be exogenous to economic and political conditions in region $\mathrm{i}$ as they reflect changes in other regions rather than regional circumstances, which could be correlated with support for the EU (for example regional party politics or regional transfers from the EU).

The exclusion restriction underlying this instrumentation strategy thus requires that Europewide industry-specific employment growth rates are uncorrelated with regional labor market conditions. It is plausible that no region is large enough to cause Europe-wide changes in an entire industry. The German region North Rhine-Westphalia is the region with the highest employment in a single sector (2.6 Mio employees in sector group G- ${ }^{15}$ ) and only accounts for $4 \%$ of total employment in that industry in 2014. Shocks to that industry in North Rhine-Westphalia are thus unlikely to cause employment changes in that industry in all of Europe. I also present robustness checks excluding not only the own region but the entire country from the calculation of total employment changes in industry $\mathrm{j}$. That ensures that country specific relations to the EU, which may also be correlated with the national labor market are not introducing a bias.

Moreover, sectoral shares have to be exogenous as well (Goldsmith-Pinkham et al., 2017). A region's sectoral composition may however be driven by some factors, which are correlated with attitudes toward the EU, such as historical events, education and demography. To address these concerns I add region fixed effects and also a set of control variables (education, demography and migration) to the regression. When adding year fixed effects the first-stage results turn insignificant due to high multicollinearity between the Bartik instrument and the fixed effects. Instead of using sectoral shares multiplied by Europe-wide growth rates I therefore only use the first part of the instrument (sectoral shares) as instruments in Section 4.4. They are strong instruments even when including time and region fixed effects. This is similar to the instrumentation strategy proposed by Algan et al. (2017).

Another threat to the validity of the instrument may be EU policies specifically targeted at regions with sectoral compositions that particularly suffer from recent changes in economic conditions. These policies may determine support for the EU and sector-specific employment changes in other regions at the same time. The EU does however not have many policy tools available which could affect sector-specific regional employment to a large extent. One of its main tools are funding programs, which are supposed to foster regional convergence (Structural Funds and the Cohesion Fund). If it was the case that the EU targeted certain region-specific

\footnotetext{
${ }^{15}$ Sector group G-J according to NACE Rev. 2 includes wholesale, retail, transport, accommodation and food services, information and communication
} 
industries the coefficient of interest would however be downward biased because the EU would support regions and sectors with negative employment changes, and the interventions would most likely have a positive impact on attitudes.

In addition, the EU could affect employment through regulations such as REACH (regulation addressing the production and use of chemical substances), Capital Requirements Directives, or roaming regulations. These regulations most likely affect employment only with a time lag (due to fixed labor contracts). I therefore present a specification controlling for lagged attitudes to capture these effects.

A recent working paper (Jaeger et al., 2017) criticizes the use of shift-share instruments in the immigration literature (as for example advanced in Card (2001)). They argue that the exclusion restriction is violated because of high serial correlation of the spatial distribution of immigrants and adjustment processes in response to previous shocks. The instrument thus combines both short-term effects of immigration and responses to previous immigrant shocks, which are endogenous. This criticism does not apply to the setting outlined in this paper because industry-specific employment changes are not highly serially correlated. ${ }^{16}$ Moreover, it is implausible that people react to experienced employment changes with a lag, so adjustment processes are unlikely in this setting.

\section{Main Results: Attitudes toward the EU}

Eurosceptic attitudes often manifest in anti-EU voting behavior and can have detrimental effects on the stability of the EU and its growth prospects. In order to disentangle the effect on euroscepticism from other characteristics of eurosceptic parties and to ensure comparability across countries the following section provides in-depth analysis of labor market conditions as determinants for eurosceptic attitudes.

\subsection{Panel Analysis}

Table 1 presents the main results of the panel analysis. Columns (1), (4) and (7) show correlations between employment changes and attitudes toward the EU without any controls. Columns (2), (5) and (8) report my preferred specification including region and year fixed effects and columns (3), (6) and (9) additionally include country specific linear time trends. As I scaled the dependent variables to lie between 0 and 100, a 1 percentage point increase in the change of the employment rate corresponds to a $\beta_{1}$ percentage point impact on the dependent variable. I will interpret all coefficients with respect to a 10 percentage point increase in the 5 -year-change of

\footnotetext{
${ }^{16}$ Jaeger et al. (2017) computed that the correlation between the predicted immigrant inflow and its lag is 0.96-0.99. In contrast, the correlation between the predicted employment change and its lag is only 0.42 . Moreover, the correlation coefficients between changes in industry-specific employment in t and t-5 are between -0.23 (Agriculture) and -0.56 (Industry).
} 
Table 1: Effect of employment changes on attitudes toward the EU

\begin{tabular}{|c|c|c|c|c|c|c|c|c|c|}
\hline & \multicolumn{3}{|c|}{ Image } & \multicolumn{3}{|c|}{ Benefit } & \multicolumn{3}{|c|}{ Membership } \\
\hline & (1) & $(2)$ & $(3)$ & $(4)$ & (5) & (6) & $(7)$ & (8) & (9) \\
\hline$\Delta$ Employment $(\%)$ & $\begin{array}{c}0.6604^{* * *} \\
(0.0861)\end{array}$ & $\begin{array}{c}0.4080^{* * *} \\
(0.0631)\end{array}$ & $\begin{array}{c}0.1824^{* * *} \\
(0.0541)\end{array}$ & $\begin{array}{c}0.5941^{* * *} \\
(0.1026)\end{array}$ & $\begin{array}{c}0.3334^{* * *} \\
(0.0744)\end{array}$ & $\begin{array}{c}0.3029^{* * *} \\
(0.0618)\end{array}$ & $\begin{array}{c}0.3644^{* * *} \\
(0.0987)\end{array}$ & $\begin{array}{c}0.1914^{* * *} \\
(0.0723)\end{array}$ & $\begin{array}{c}0.1582^{* *} \\
(0.0631)\end{array}$ \\
\hline Year FE & & $\checkmark$ & $\checkmark$ & & $\checkmark$ & $\checkmark$ & & $\checkmark$ & $\checkmark$ \\
\hline Region FE & & $\checkmark$ & $\checkmark$ & & $\checkmark$ & $\checkmark$ & & $\checkmark$ & $\checkmark$ \\
\hline Country FE x Year & & & $\checkmark$ & & & $\checkmark$ & & & $\checkmark$ \\
\hline adj. $R^{2}$ & 0.05 & 0.63 & 0.69 & 0.03 & 0.63 & 0.69 & 0.01 & 0.60 & 0.69 \\
\hline $\mathrm{N}$ & 2,668 & 2,668 & 2,668 & 2,950 & 2,950 & 2,950 & 2,950 & 2,950 & 2,950 \\
\hline Cluster & 265 & 265 & 265 & 264 & 264 & 264 & 264 & 264 & 264 \\
\hline Mean DV & 43.86 & 43.86 & 43.86 & 61.01 & 61.01 & 61.01 & 53.92 & 53.92 & 53.92 \\
\hline
\end{tabular}

OLS estimations. Image, Benefit and Membership are outcome variables based on Eurobarometer survey questions and are coded to lie between 0 and 100 . Change of employment rate is computed over five years. Standard errors (clustered by region) in parentheses. ${ }^{* * *} \mathrm{p}<0.01,{ }^{* *} \mathrm{p}<0.05,{ }^{*} \mathrm{p}<0.1$. 
the employment rate, which is roughly analogous to a 2 percentage point increase per year. ${ }^{17}$ All coefficients on change of employment rate are statistically significant on the $1 \%$ level. A 10 percentage point increase in the change of the employment rate corresponds to an increase of roughly 4 percentage points on the image scale (column (2)), a 3 percentage point increase on the benefit scale (column (5)) and a 2 percentage point increase on the membership scale (column (8)). These effect sizes correspond to 0.1 to 0.3 standard deviations of the dependent variables. Compared to the means of the dependent variables (44 for image, 65 for benefit and 61 for membership) a 10 percentage point increase in employment change raises support for the EU by $5-10 \%$ of the sample average of the dependent variables.

In order to account for potential reversed causality problems I include lagged dependent variables to the model. They capture past attitudes and also its policy reactions. The number of observations decreases in these specifications as I loose the first four years in each series due to the five year time lags. The specification with image as dependent variable thus spans the period 2005-2014 and the membership and benefit specifications the time period 1998-2011. ${ }^{18}$ The effects on image of EU and perceived benefit are still statistically significant and of roughly the same magnitude as the baseline effects (Table 2). The effect on the assessment of the country's EU membership is not statistically significant anymore (p-value of 0.16 ).

One concern in this setting may be Nickell bias due to a mechanical correlation between the lagged dependent variable and the error term, which vanishes with an increasing number of observations over time (Nickell, 1981). Judson and Owen (1999) show that the bias of the least square dummy variable (LSDV) estimator for dynamic panel data models is sizable even in panels with 20 time periods. I therefore present robustness checks using a bias-corrected LSDV estimator, which estimates a bootstrap variance-covariance matrix for the corrected estimator (Bruno, 2005) (see Table A8 in the Appendix). Judson and Owen (1999) provide Monte Carlo evidence that the corrected LSDV estimator performs better than traditional GMM estimators. The estimated effects of changes in the employment rate are very similar in the panel fixed effect set-up and the bias corrected fixed effect estimation irrespective of whether the correction is being initialized by the Anderson-Hsiao or Arellano-Bond estimator.

The panel results are robust to a number of checks. First, I investigate the sensitivity of the results to the definition of the main explanatory variable. For this purpose I estimate the effect for different time horizons of employment changes, i.e. employment changes between $t$ and $t-1, t-$ 2 , $t-3$ etc. up to $t-10$. The effect on the image of the EU declines slightly for longer time horizons (the effect of a 1-year change amounts to 0.42 while the effect of a 10-year change is 0.32 ) but remains still statistically significant (see Figure A4). I also binarize changes in the employment rate and thus only distinguish between negative and positive changes. The effects on image and benefit are still highly statistically significant and quantitatively similar to the baseline effect.

\footnotetext{
${ }^{17}$ The mean negative change is $-4.2 \%$ and the mean positive change is $+4.2 \%$. The standard deviation of change of employment rate is 5.5 .

${ }^{18}$ The number of regions covered in the Eurobarometer survey decreased in 2004 (higher level of aggregation for German and British regions). Therefore the number of regions covered by the regressions also decreases.
} 
Table 2: Effect of employment changes on attitudes toward the EU

\begin{tabular}{|c|c|c|c|}
\hline & $\begin{array}{c}(1) \\
\text { Image }\end{array}$ & $\begin{array}{c}(2) \\
\text { Benefit }\end{array}$ & $\begin{array}{c}(3) \\
\text { Membership }\end{array}$ \\
\hline$\Delta$ Employment $(\%)$ & $\begin{array}{c}0.4845^{* * *} \\
(0.0914)\end{array}$ & $\begin{array}{c}0.3247^{* * *} \\
(0.1086)\end{array}$ & $\begin{array}{c}0.1311 \\
(0.0941)\end{array}$ \\
\hline Image $_{t-5}$ & $\begin{array}{l}-0.0675 \\
(0.0484)\end{array}$ & & \\
\hline Benefit $_{t-5}$ & & $\begin{array}{c}0.0658^{* *} \\
(0.0320)\end{array}$ & \\
\hline Membershipt-5 $_{\text {te }}$ & & & $\begin{array}{c}0.0392 \\
(0.0488)\end{array}$ \\
\hline Region FE & $\checkmark$ & $\checkmark$ & $\checkmark$ \\
\hline Year FE & $\checkmark$ & $\checkmark$ & $\checkmark$ \\
\hline $\operatorname{adj} . R^{2}$ & 0.62 & 0.64 & 0.65 \\
\hline $\mathrm{N}$ & 1,570 & 1,742 & 1,742 \\
\hline Cluster & 206 & 249 & 249 \\
\hline Mean DV & 40.67 & 62.26 & 54.65 \\
\hline
\end{tabular}

Experiencing positive employment growth rather than negative increases the image of the EU by 3 percentage points and the perceived benefit from the EU by 2 percentage points (see Appendix Table A9). The effect on membership is again not significant (p-value of 0.13 ) but quantitatively similar to the baseline. Next, I estimate the effect of absolute employment changes and changes in active population separately to show that the effects are indeed driven by employment dynamics rather than population dynamics. The effects of absolute employment changes are still highly significant and of similar size as the baseline. Changes in active population have no significant effect on attitudes (see Appendix Table A10). I then include the level of the employment rate as control variable (see Appendix Table A11). The coefficients decrease slightly in magnitude as compared to the baseline but remain all statistically significant. The effect of the employment rate is positive and for the image and benefit outcomes statistically significant. A 10 percentage point increase in the employment rate corresponds to a 5 percentage point increase on the image scale.

Second, I also estimate the effect of changes in the employment rate on a combined EU support index, which is based on all three outcome variables and also ranges from 0 to 100. It is only available for the period 2001-2011. Here, a 10 percentage point decrease in the change of the employment rate corresponds to a decline by 3 points of the index, which has a sample mean of 57 and a standard deviation of 15 (see Appendix Table A12). 
Third, I add a number of control variables in order to substantiate the argument. I control for the evaluation of national institutions (national government and national parliament) to demonstrate that I capture an effect above and beyond attitudes toward politics or politicians in general (see Appendix Table A13). ${ }^{19}$ The effect of employment changes on attitudes toward the EU remains significant for the image and benefit outcome- albeit smaller than in the baseline (around half the size). The effect on membership becomes insignificant. I also add trust in EU parliament as an additional outcome to make it comparable to the questions about national institutions. For this outcome, I also find a statistically significant effect even when controlling for trust in national parliament and government. Hence, holding the evaluation of national institutions constant employment changes still affect attitudes toward the EU. That shows that people explicitly attribute changes in the labor market conditions at least to some degree to the European Union. Interestingly, I find a highly significant and large positive effect of trust in national parliament on attitudes toward EU but an insignificant and small (for membership even negative) effect of trust in national government on attitudes even though trust in national government and trust in national parliament are highly correlated (correlation coefficient of 0.91). Finally, I show that the results are also robust to including education, median age, old-age ratio and migration as control variables (see Appendix Table A14).

Lastly, I explore heterogeneities of the employment effect with respect to country groups. I find that the employment effect is strongest for southern and eastern European countries (see Figure A5). It is mainly driven by Greece, Portugal, Spain and Slovenia, Czech Republic and Hungary (see Figure A6). These countries suffered particularly from the financial crisis, which supports the findings of Algan et al. (2017), who emphasize the negative effect of the Great Recession on trust in European political institutions.

\subsection{Potential Mechanisms}

In this section I investigate potential mechanisms driving the effect of changes in labor market conditions on attitudes. First, I distinguish between positive and negative changes in order to determine whether the effect is driven by regions that experienced a deterioration in labor market conditions or by regions that experienced an improvement. It turns out that negative employment changes have a highly significant and much larger effect on attitudes than the baseline (see Appendix Table A17). A 10 percentage point decrease in the change of the employment rate, raises the image of the EU by 8 percentage points and improves the evaluation of both benefit and membership by 5 points. The effects for the sup-sample of negative employment changes are thus roughly twice the size of the baseline effects. The effect of positive changes is however not statistically different from zero. These results indicate that negative changes in employment are associated with the EU while positive changes are not.

\footnotetext{
${ }^{19}$ Algan et al. (2017) find that changes in unemployment affect trust toward national and European political institutions.
} 
Table 3: Effect of employment changes on attitudes toward the EU

\begin{tabular}{|c|c|c|c|c|}
\hline & $\begin{array}{c}(1) \\
\text { Image }\end{array}$ & $\begin{array}{c}(2) \\
\text { Image }\end{array}$ & $\begin{array}{c}(3) \\
\text { Image }\end{array}$ & $\begin{array}{c}(4) \\
\text { Image }\end{array}$ \\
\hline$\Delta$ Employment (\%) & $\begin{array}{l}0.1602^{* *} \\
(0.0738)\end{array}$ & $\begin{array}{c}0.2289 * * * \\
(0.0805)\end{array}$ & $\begin{array}{c}0.2342^{* * *} \\
(0.0724)\end{array}$ & $\begin{array}{c}0.2480 * * * \\
(0.0735)\end{array}$ \\
\hline Working age (18-65) & $\begin{array}{c}0.9361^{* *} \\
(0.4490)\end{array}$ & & & \\
\hline $\begin{array}{l}\text { Working age }(18-65) \times \\
\Delta \text { Employment }(\%)\end{array}$ & $\begin{array}{c}0.1446 * * * \\
(0.0534)\end{array}$ & & & \\
\hline Active Population & & $\begin{array}{c}1.3948^{* * *} \\
(0.4215)\end{array}$ & & \\
\hline $\begin{array}{l}\text { Active Population } \times \\
\Delta \text { Employment }(\%)\end{array}$ & & $\begin{array}{c}0.0643 \\
(0.0518)\end{array}$ & & \\
\hline Unemployed & & & $\begin{array}{c}-7.7969^{* * *} \\
(0.4773)\end{array}$ & \\
\hline $\begin{array}{l}\text { Unemployed } \times \\
\Delta \text { Employment }(\%)\end{array}$ & & & $\begin{array}{l}0.1051^{*} \\
(0.0613)\end{array}$ & \\
\hline Low-skilled & & & & $\begin{array}{c}-11.3862^{* * *} \\
(0.4236)\end{array}$ \\
\hline $\begin{array}{l}\text { Low-skilled } \times \\
\Delta \text { Employment }(\%)\end{array}$ & & & & $\begin{array}{c}0.1672^{* *} \\
(0.0705)\end{array}$ \\
\hline Region FE & $\checkmark$ & $\checkmark$ & $\checkmark$ & $\checkmark$ \\
\hline Year FE & $\checkmark$ & $\checkmark$ & $\checkmark$ & $\checkmark$ \\
\hline $\operatorname{adj.} R^{2}$ & 0.06 & 0.06 & 0.06 & 0.07 \\
\hline $\mathrm{N}$ & 520,233 & 520,104 & 520,233 & 411,137 \\
\hline Cluster & 265 & 265 & 265 & 265 \\
\hline Mean DV & 44.30 & 44.30 & 44.30 & 43.28 \\
\hline
\end{tabular}

OLS estimations. Image, Benefit and Membership are outcome variables based on Eurobarometer survey questions and are coded to lie between 0 and 100. Change of employment rate is computed over five years. Working age is defined as 18 to 65 years. Active population consists of both employed and unemployed as opposed to students, house persons and retired people. 'Low-skilled' consists of people who left education before the age of 16 . Standard errors (clustered by region) in parentheses. $* * * \mathrm{p}<0.01, * * \mathrm{p}<0.05, * \mathrm{p}<0.1$. 
In order to understand who is particularly affected by these negative changes I analyze individuallevel data in a next step. Several studies have documented that people who benefited from European integration (educated and high-skilled citizens) have higher support for EU membership and have higher trust in European institutions (Foster and Frieden, 2017; Frieden, 2016; Algan et al., 2017; Becker et al., 2017) ${ }^{20}$ I therefore analyze these characteristics in greater detail.

Table A15 presents estimates of the baseline model including individual level controls (age, gender and education dummies) using all individual-level observations rather than region aggregates. The effects of employment changes are all statistically significant and quantitatively similar to the baseline results. ${ }^{21}$ Here the outcome variables are binary (instead of regional averages as in the baseline) and to account for the discrete nature of the dependent variable I also show that the results hold when applying a logit model (see Appendix Table A16). Next, I explore interaction effects between changes in the employment rate and groups in society that may be particularly affected by changes in the labor market. First, I create a dummy for the working age population (18-65) and I find that the effect of changes in the employment rate is particularly strong for this group (Table 3, column (1)). Then I analyze heterogeneous effects with respect to the active population (employed or actively seeking employment). The interaction between changes in the employment rate and active population is positive however not statistically significant (Table 3, column (2)). ${ }^{22}$ The effect of employment changes on attitudes is reinforced if someone is unemployed (Table 3, column (3)). Finally I also find that the effect is particularly strong for the low-skilled. ${ }^{23}$ While the effect of a change of the employment rate on the image of the EU is around 0.25 for the high-skilled it amounts to 0.42 for the low-skilled (Table 3, column (4)). These findings support the hypothesis that the effect of labor market changes on attitudes toward the EU is driven by the so-called 'left-behind'. Both unemployed and unskilled may feel threatened by a deterioration in the labor market conditions and blame the EU.

It is difficult to identify reasons why those with gloomy perspectives on the labor market associate changes in labor market conditions with the EU. One reason may be fear of foreign migration. Becker and Fetzer (2016) show for the UK that increased migration from Eastern Europe (which is relatively low-skilled) increased the vote share for the eurosceptic UK Independence Party. I therefore control for the share of EU migration and examine an interaction effect between changes in employment and migration. I conduct these analysis only for the image outcome as regional data on EU migration is only available since $2006 .{ }^{24}$ The series for benefit and

\footnotetext{
${ }^{20}$ This line of argument is based on utilitarian explanations for public support of European integration (Hobolt and de Vries, 2016).

${ }^{21}$ The differences in the size of the coefficients are due to the weighting of observations. While in the baseline each region-year pair receives equal weights, in this specification the unit of observation are individuals.

${ }^{22}$ Self-employed, managers, other white collar workers, manual workers and unemployed as opposed to house persons, retired and students.

${ }^{23}$ People with up to 15 years of education as opposed to people with 16 or more years of education. Students are excluded.

${ }^{24}$ For that reason I also only observe 162 regions rather than 265 as in the previous regressions. Since 2004 Eurobarometer data is available for fewer, more aggregated regions in Germany and the UK.
} 
Table 4: Effect of employment changes on attitudes toward the EU: interaction with EU migration

\begin{tabular}{|c|c|c|c|c|}
\hline & $\begin{array}{l}(1) \\
\text { Image }\end{array}$ & $\begin{array}{l}(2) \\
\text { Image }\end{array}$ & $\begin{array}{c}(3) \\
\text { Image }\end{array}$ & $\begin{array}{c}(4) \\
\text { Image }\end{array}$ \\
\hline$\Delta$ Employment Rate & $\begin{array}{c}0.5835^{* * *} \\
(0.1113)\end{array}$ & $\begin{array}{c}0.6020^{* * *} \\
(0.1218)\end{array}$ & $\begin{array}{c}0.7288^{* * *} \\
(0.1199)\end{array}$ & $\begin{array}{c}0.8255^{* * *} \\
(0.1494)\end{array}$ \\
\hline Share EU migrants & $\begin{array}{c}0.8843^{* * *} \\
(0.3233)\end{array}$ & $\begin{array}{c}1.2694^{* * *} \\
(0.4103)\end{array}$ & & \\
\hline $\begin{array}{l}\Delta \text { Employment Rate } \times \\
\text { Share EU migrants }\end{array}$ & $\begin{array}{c}0.0087 \\
(0.0097)\end{array}$ & $\begin{array}{c}0.0121 \\
(0.0114)\end{array}$ & & \\
\hline $\begin{array}{l}\text { Low-skilled } \times \Delta \text { Employment Rate } \times \\
\text { Share EU migrants }\end{array}$ & & $\begin{array}{l}0.0131^{*} \\
(0.0070)\end{array}$ & & \\
\hline LS EU/LS Home & & & $\begin{array}{c}0.8692^{* * * *} \\
(0.1870)\end{array}$ & $\begin{array}{c}0.7210^{* * *} \\
(0.2573)\end{array}$ \\
\hline $\begin{array}{l}\Delta \text { Employment Rate } \times \\
\text { LS EU/LS Home }\end{array}$ & & & $\begin{array}{l}-0.0027 \\
(0.0040)\end{array}$ & $\begin{array}{l}-0.0040 \\
(0.0041)\end{array}$ \\
\hline $\begin{array}{l}\text { Low-skilled } \times \Delta \text { Employment Rate } \times \\
\text { LS EU/LS Home }\end{array}$ & & & & $\begin{array}{l}0.0152^{*} \\
(0.0079)\end{array}$ \\
\hline Region FE & $\checkmark$ & $\checkmark$ & $\checkmark$ & $\checkmark$ \\
\hline Year FE & $\checkmark$ & $\checkmark$ & $\checkmark$ & $\checkmark$ \\
\hline $\operatorname{adj} . R^{2}$ & 0.05 & 0.06 & 0.06 & 0.07 \\
\hline $\mathrm{N}$ & 225,099 & 177,401 & 184,183 & 145,343 \\
\hline Cluster & 162 & 162 & 147 & 145 \\
\hline Mean DV & 41.30 & 40.75 & 42.38 & 41.93 \\
\hline
\end{tabular}

OLS estimations. The image outcome variable is based on a Eurobarometer survey question and is coded to lie between 0 and 100. Change of employment rate is computed over five years. Interaction terms between low-skilled and $\Delta$ employment rate and between low-skilled and share EU migrants/share lowskilled EU migrants are included in the estimation model but not reported in the table. Standard errors (clustered by region) in parentheses. ${ }^{* * *} \mathrm{p}<0.01,{ }^{*} \mathrm{p}<0.05,{ }^{*} \mathrm{p}<0.1$. 
membership would be too short. Surprisingly, the effect of EU migration on attitudes toward the EU is significantly positive and the effect is even larger than the employment effect (Table 4, column (1)). People living in regions with a high share of EU migrants thus tend to have a better image of the EU. This provides support for the 'contact hypothesis' (Allport, 1954), which states that contact is one of the most effective ways to reduce prejudice. The interaction effect between EU migration and employment changes is insignificant. The effect of employment changes on the image of the EU therefore does not seem to be driven by actual migration. In the previous paragraph I demonstrated that the effect is particularly strong for the lowskilled. This part of society may feel particularly threatened by migration due to an increase in perceived job insecurity and concerns about wage reductions (NAS, 2017; Dustmann et al., 2005, 2013; Borjas, 2003). The interaction between low-skilled, employment change and share of EU migrants indeed reveals a significant positive effect (Table 4, column (2)) ${ }^{25}$ The employment effect is thus stronger for low-skilled people in regions with a high share of EU migrants. These findings are in line with Dustmann et al. (2017, p. 14) conclusion from a literature review about immigration and economic adjustment: "Overall, however, it is fair to say that negative effects on native wages, if present, are relatively modest and are restricted to those groups that are in direct competition with immigrants."

In a next step, I focus on low-skilled EU migration as this type of migration may threaten local low-skilled workers most. For this purpose I include the ratio between low-skilled EU migrants to low-skilled local citizens (LS EU/LS Home) to the model. Again, the interaction between this low-skilled migration ratio and employment changes has no effect on attitudes in general (Table 4, column (3)). When interacting this term with the low-skilled dummy (Table 4, column (4)) the effect becomes statistically significant. This finding demonstrates that low-skilled locals are particularly sensitive to employment changes in the presence of a large share of low-skilled EU migrants.

Finally, I investigate whether the effect of changes in attitudes toward the EU is related to EU policies, i.e. EU migration, or driven by discontent with globalization in general. As a placebo check I therefore estimate the effect of non-EU (low-skilled) migration on attitudes toward the EU. Table A18 shows that there is neither an effect of share of non-EU migrants on image of EU (column (1)), nor interaction effects between the share of non-EU migrants, changes in employment and the low-skilled dummy (column (2)). I also do not find significant effects of the share of low-skilled non-EU migrants and its interaction with employment changes and lowskilled local workers (Table A18, columns (3) and (4)). These findings suggest that the effect of employment changes interacted with a dummy for low-skilled locals and the EU migration rate is unique to EU migration and does not pick up effects of migration or frustration with globalization in general.

\footnotetext{
${ }^{25}$ I estimate the fully specified model:

$E U$ Attitude $_{r t}=\beta_{0}+\beta_{1} \Delta$ Employment $_{\text {Rate }}+\beta_{3}$ Share EU Migrants $_{r t}+\beta_{4}$ Low $_{\text {skilled }}$ irt + $\beta_{5} \Delta$ Employment Rate $_{r \tau} *$ Low skilled $_{i r t}+\beta_{6} \Delta$ Employment Rate $_{r \tau} *$ Share EU Migrants S $_{r t}+$ $\beta_{7}$ Low skilled $_{\text {irt }} *$ Share EU Migrants S $_{r t}+\beta_{8} \Delta$ Employment Rate $_{r \tau} *$ Share EU Migrants $_{r t} *$ Low $_{\text {skilled }}$ Sirt $_{+}+$ $\mu_{t}+\delta_{r}+u_{r t}$
} 
Table 5: First-stage regression

\begin{tabular}{|c|c|c|c|}
\hline & $\begin{array}{c}(1) \\
\Delta \text { Employment }\end{array}$ & $\begin{array}{c}(2) \\
\Delta \text { Employment }\end{array}$ & $\begin{array}{c}(3) \\
\Delta \text { Employment }\end{array}$ \\
\hline Bartik $\Delta$ Employment & $\begin{array}{c}0.523^{* * *} \\
(0.0670)\end{array}$ & $\begin{array}{c}0.892^{* * *} \\
(0.0745)\end{array}$ & $\begin{array}{c}0.777^{* * *} \\
(0.102)\end{array}$ \\
\hline Region FE & & $\checkmark$ & $\checkmark$ \\
\hline Controls & & & $\checkmark$ \\
\hline $\operatorname{adj} . R^{2}$ & 0.06 & 0.23 & 0.31 \\
\hline $\mathrm{N}$ & 4,366 & 4,366 & 3,095 \\
\hline Cluster & 286 & 286 & 278 \\
\hline F-Test & 60.98 & 143.44 & 57.92 \\
\hline \multicolumn{4}{|c|}{$\begin{array}{l}\text { OLS estimations for the period } 1996-2014 \text { (columns }(1) \text { and }(2) \text { ) and } 2000-2014 \text { (column } \\
\text { (3). Image, Benefit and Membership are outcome variables based on Eurobarometer survey } \\
\text { questions and are coded to lie between } 0 \text { and } 100 \text {. Controls include education (share of } \\
\text { population with primary education, share of population with secondary education, share of } \\
\text { population with tertiary education), demographic variables (median age and old-age ratio) } \\
\text { and migration rate. Standard errors (clustered by region) in parentheses. }{ }^{* * *} \mathrm{p}<0.01 \text {, } \\
\mathrm{p}<0.05 \text {, }^{*} \mathrm{p}<0.1 \text {. }\end{array}$} \\
\hline
\end{tabular}

\subsection{Two-Stage Least Squares Analysis}

In this section I present results of Two-Stage Least Squares (2SLS) regressions using regional industrial composition multiplied with Europe-wide employment changes in those industries as an instrument. Table 5 shows the effect of predicted employment changes based on the the Bartik instrument on actual employment changes. ${ }^{26}$ In this model I use variation in shocks to certain industries over time (these shocks are roughly the same for all regions in each year) and variation in the industry composition across regions and over time.

The first column shows the effect of predicted employment on actual employment. A 1 percentage point increase in predicted employment change is associated with a 0.5 percentage point increase in actual employment change. The Kleinbergen-Paap rk Wald F statistic is well above 10 and the instrument is thus highly relevant. ${ }^{27}$ In column (2) I add region fixed effects to capture all region-specific factors, which may affect the regional industry composition and total employment changes. I thus rely on variation within regions over time. This yields an F-statistic of 143 and a statistically significant effect of 0.9. Finally, I add socio-demographic controls (education, demography and migration). In this specification a 1 percentage point increase in predicted employment change is associated with a 0.8 percentage point increase in actual employment change and the F-statistic is 58 (column (3)). I will present 2SLS results for all specifications.

The 2SLS results confirm the findings from the panel analysis. There is a statistically significant positive relationship between changes in the employment rate and attitudes toward the EU. The effect sizes are however not comparable as specifications differ (the 2SLS analysis does

\footnotetext{
${ }^{26}$ Bartik Employment $_{i t}=\sum_{j} \frac{\text { Employment }_{j i t}}{\text { Active Population }_{i t}} * \Delta$ Employment $_{\text {Rate }}^{-i}$

${ }^{27}$ The Kleinbergen-Paap rk Wald F statistic is also well above the Stock-Yogo critical values in all specifications.
} 
Table 6: 2SLS estimations: effect of employment changes on attitudes toward the EU

\begin{tabular}{|c|c|c|c|c|c|c|c|c|c|}
\hline & \multicolumn{3}{|c|}{ Image } & \multicolumn{3}{|c|}{ Benefit } & \multicolumn{3}{|c|}{ Membership } \\
\hline$\Delta$ Employment $(\%)$ & $\begin{array}{c}1.354^{* * *} \\
(0.409)\end{array}$ & $\begin{array}{c}2.938^{* * *} \\
(0.236)\end{array}$ & $\begin{array}{c}1.979 * * * \\
(0.328)\end{array}$ & $\begin{array}{c}-1.630^{*} \\
(0.893)\end{array}$ & $\begin{array}{c}1.609^{* * *} \\
(0.178)\end{array}$ & $\begin{array}{c}1.963^{* * *} \\
(0.508)\end{array}$ & $\begin{array}{c}1.232^{*} \\
(0.648)\end{array}$ & $\begin{array}{c}1.207^{* * *} \\
(0.172)\end{array}$ & $\begin{array}{c}1.203^{* * *} \\
(0.413)\end{array}$ \\
\hline Region FE & & $\checkmark$ & $\checkmark$ & & $\checkmark$ & $\checkmark$ & & $\checkmark$ & $\checkmark$ \\
\hline Controls & & & $\checkmark$ & & & $\checkmark$ & & & $\checkmark$ \\
\hline Cluster & 265 & 265 & 261 & 264 & 264 & 259 & 264 & 264 & 259 \\
\hline 1st stage F-Test & 48.05 & 102.10 & 50.39 & 21.82 & 120.39 & 22.71 & 21.82 & 120.39 & 22.71 \\
\hline Mean DV & 43.50 & 43.50 & 43.33 & 60.89 & 60.89 & 62.32 & 53.82 & 53.82 & 54.10 \\
\hline
\end{tabular}

2SLS estimations. Image, Benefit and Membership are outcome variables based on Eurobarometer survey questions and are coded to lie between 0 and 100. Change of employment rate is computed over five years. Controls include education (share of population with primary education, share of population with secondary education, share of population with tertiary education), demographic variables (median age and old-age ratio) and migration rate. Kleibergen-Paap rk Wald F statistic reported. Standard errors (clustered by region) in parentheses. $* * * \mathrm{p}<0.01,{ }^{* *} \mathrm{p}<0.05,{ }^{*} \mathrm{p}<0.1$. 
not include year fixed effects). I will discuss the comparison of effect sizes using an alternative instrumentation strategy in Section 4.4. In this setting, I find that a 10 percentage point increase in the change of the employment rate is associated with an increase by 14 percentage points on the image scale relative to a mean of around 44 and a standard deviation of 15 (Table 6, column (1)). It is puzzling that the effect on benefit from the EU is negatively significant (Table 6 ,column (4)). It however turns positive and becomes statistically significant when including region fixed effects and control variables (Table 6, columns (5) and (6)). The effect of changes in the employment rate on the membership outcome are also significantly positive (Table 6, columns (7)-(9)).

As robustness check and to account for past attitudes I include the fifth lag of the dependent variables to the 2SLS specifications (see Appendix Table A19). Most coefficients on change of the employment rate are highly statistically significant and even larger than in the baseline 2SLS regressions. A 10 percentage point increase in the change of the employment rate is for example associated with a roughly 30 percentage point increase on the image of the EU scale (column (1)). Column (3) displays the effect of changes of the employment rate on perceived benefit from the EU and this effect is now positive (as opposed to the specification without lagged dependent variable) however not statistically significant (p-value of 0.16 ). Not surprisingly, the lags of the dependent variable have a positive and quite sizable (coefficients between 0.1 and 0.6) effect on contemporary attitudes.

As an additional robustness check I exclude the own country in the calculation of the Bartik instrument (Appendix Table A20). The results are very similar to the 2SLS baseline. Gaining a bit more credibility for the exclusion restriction comes at the expense of relevance. The Fstatistic is only slightly greater than 10 in some specifications (i.e. 10.03 in the specification without any fixed effects for the benefit and membership outcomes). Finally, I also estimate the 2SLS model with individual level observations and individual characteristics as controls. Again, the results also hold in this setting (see Appendix Table A21).

\subsection{Comparison of Panel and 2SLS Results}

The coefficients on the 2SLS regressions in Section 4.3 are not comparable with those of the OLS regressions in Section 4.1, because of differences in specification. The preferred specification in the panel setup was to use both region and year fixed effects. This specification does not lend itself to a Bartik-type instrument, because the inclusion of year fixed effects absorbs explanatory power from the Bartik instrument and it becomes weak (Kleibergen-Paap rk Wald F statistic for the first stage falls to 4.3). ${ }^{28}$ The first-stage however improves drastically when only using the first part of the Bartik instrument, the lagged sectoral shares to predict employment changes (Kleibergen-Paap rk Wald F statistic is 51.4). By using the fifth lag of the sectoral shares as instruments I isolate the component of employment changes stemming from industrial

\footnotetext{
${ }^{28}$ The vector inflation factor for the Bartik instrument is around 16.
} 
Table 7: Comparison between panel and 2SLS results

\begin{tabular}{|c|c|c|c|c|c|c|}
\hline & \multicolumn{2}{|c|}{ Image } & \multicolumn{2}{|c|}{ Benefit } & \multicolumn{2}{|c|}{ Membership } \\
\hline & $(1)$ & $(2)$ & $(3)$ & $(4)$ & $(5)$ & (6) \\
\hline & Panel & IV & Panel & IV & Panel & IV \\
\hline$\Delta$ Employment $(\%)$ & $\begin{array}{c}0.2972^{* * *} \\
(0.0657)\end{array}$ & $\begin{array}{c}0.5090^{* * *} \\
(0.1136)\end{array}$ & $\begin{array}{c}0.2971^{* * *} \\
(0.0906)\end{array}$ & $\begin{array}{c}0.4795^{* * *} \\
(0.1410)\end{array}$ & $\begin{array}{c}0.1836^{* *} \\
(0.0867)\end{array}$ & $\begin{array}{l}0.2017^{*} \\
(0.1217)\end{array}$ \\
\hline Year FE & $\checkmark$ & $\checkmark$ & $\checkmark$ & $\checkmark$ & $\checkmark$ & $\checkmark$ \\
\hline Region FE & $\checkmark$ & $\checkmark$ & $\checkmark$ & $\checkmark$ & $\checkmark$ & $\checkmark$ \\
\hline Controls & $\checkmark$ & $\checkmark$ & $\checkmark$ & $\checkmark$ & $\checkmark$ & $\checkmark$ \\
\hline adj. $R^{2}$ & 0.65 & 0.65 & 0.66 & 0.66 & 0.66 & 0.66 \\
\hline $\mathrm{N}$ & 2,552 & 2,552 & 2,083 & 2,083 & 2,083 & 2,083 \\
\hline Cluster & 261 & 261 & 259 & 259 & 259 & 259 \\
\hline Mean DV & 43.71 & 43.71 & 62.46 & 62.46 & 54.23 & 54.23 \\
\hline F-Test & & 42.44 & & 44.26 & & 44.26 \\
\hline
\end{tabular}

Panel and 2SLS estimations including year and region fixed effects. Image, Benefit and Membership are outcome variables based on Eurobarometer survey questions and are coded to lie between 0 and 100. Change of employment rate is computed over five years. Instruments for the change of employment rate are employment share in agriculture, employment share in industry, employment share in construction, employment share in wholesale, employment share in financial services and employment share in non-market services. KleibergenPaap rk Wald F statistic reported for 2SLS estimations. Control variables include share of population with primary education (in \%), share of population with secondary education (in \%), share of population with tertiary education (in \%), median age, old age ratio (65 and above compared to 15-65 year olds) and crude rate of net migration plus adjustment. Standard errors (clustered by region) in parentheses. ${ }^{* * *} \mathrm{p}<0.01,{ }^{* *}$ $\mathrm{p}<0.05, * \mathrm{p}<0.1$ 
specialization and account for year effects separately (the Bartik instrument combines these two dimensions as Europe-wide industry-specific growth rates are constant for all regions). It seems plausible that the impact of sectoral specialization on support for the EU works mainly through the labour market, especially in the short term. Just as for the Bartik instrument, regional demography, education and migration may nevertheless constitute threats to the validity of the instruments. I therefore include these factors as controls in the panel and 2SLS setting.

Table 7 presents the results of the panel and IV models using sectoral shares as instruments. While I find in the panel analysis that a 10 percentage point increase in the change of the employment rate is associated with a 3 percentage point increase on the image scale (column (1)) I estimate an increase by 5 percentage points in the 2SLS setting (column (2)). I also find larger 2SLS coefficients for the benefit and membership outcomes (columns (3)-(6)).

The fact that $\hat{\beta}^{O L S}<\hat{\beta}^{2 S L S}$ indicates that the OLS estimates may have been downward biased. This could be the case if for example EU policies were targeted at regions with extremely negative employment changes and thereby mitigated the effect that I estimated in the panel specification. Other omitted factors in the panel analysis may include media reporting or activities of local politicians. It is however reassuring that I find qualitatively a similar pattern- a positive effect of changes in the employment rate on attitudes toward the EU- in both setups.

\section{Additional Results: Voting}

Empowering nationalistic anti-globalization parties may have dramatic consequences for trade policies, immigration policies and international cooperation and thus growth prospects. It is therefore not only important to better understand the determinants of attitudinal euroscepticism but also of eurosceptic voting behavior. This analysis is therefore based on voting behavior in five European Parliament elections (1994, 1999, 2004, 2009, 2014). Throughout all different specifications I find significantly positive effects of changes in the employment rate on pro-EU voting. A 10 percentage point increase in the change of the employment rate raises the pro-EU voting index by roughly 4 points on a scale from 0 to 100 (Table 8, column (1)). Greece for example had a rather low pro-EU index in 2014 (37 as compared to a Europe-wide mean of 56). Between 2009 and 2014 it experienced a decline in the employment rate of 13 percentage points. Had the employment rate only decreased by 3 percentage points and holding everything else constant, the pro-EU index would lie around 41 according to the model. A 10 percentage point increase in the change of the employment rate would have thus corresponded to a roughly $10 \%$ improvement in Greece's pro-EU voting index. When including region and year fixed effects (column (2)) and country specific linear time trends (column (3)) the size of the coefficient remains constant and statistically significant at the $1 \%$ level. The coefficient is also highly significant in the 2SLS specification using the Bartik instrument (column (4)). The coefficient should however be interpreted with caution as the first-stage F-statistic is only marginally above 
Table 8: Effect of employment changes on pro-EU voting

\begin{tabular}{lccccc}
\hline & $(1)$ & $(2)$ & $(3)$ & $(4)$ & $(5)$ \\
& $\begin{array}{c}\text { Pro EU Voting } \\
\text { OLS }\end{array}$ & $\begin{array}{c}\text { Pro EU Voting } \\
\text { OLS }\end{array}$ & $\begin{array}{c}\text { Pro EU Voting } \\
\text { OLS }\end{array}$ & $\begin{array}{c}\text { Pro EU Voting } \\
\text { 2SLS } \\
\text { (Bartik) }\end{array}$ & $\begin{array}{c}\text { Pro EU Voting } \\
\text { 2SLS } \\
\text { (Sectoral Shares) }\end{array}$ \\
\hline$\Delta$ Employment (\%) & $0.3813^{* * *}$ & $0.3802^{* * *}$ & $0.3552^{* * *}$ & $2.7035^{* * *}$ & $0.4699^{* * *}$ \\
& $(0.0912)$ & $(0.0978)$ & $(0.0881)$ & $(0.6734)$ & $(0.1602)$ \\
\hline Year FE & & $\checkmark$ & $\checkmark$ & & $\checkmark$ \\
Region FE & & $\checkmark$ & $\checkmark$ & $\checkmark$ & $\checkmark$ \\
Country FE x Year & & & $\checkmark$ & & \\
F-Test & & & & 71.81 & 785 \\
N & 780 & 780 & 780 & 234.72 \\
Cluster & 234 & 234 & 234 & 234 & 234 \\
Mean DV & 56.41 & 56.41 & 56.41 & 56.30 & 56.41 \\
\hline
\end{tabular}

OLS and 2SLS estimations. The pro-EU voting index is based on a party's pro-EU score (assigned by Euromanifesto) and its vote share in the EP elections in 1994, 1999, 2004, 2009 and 2014. It is scaled to lie between 0 and 100. Change of employment rate is computed over five years. Kleibergen-Paap rk Wald F statistic reported. Standard errors (clustered by region) in parentheses. ${ }^{* * *}$ $\mathrm{p}<0.01,{ }^{* *} \mathrm{p}<0.05,{ }^{*} \mathrm{p}<0.1$. 
10 (11.8) and the instrument may therefore be weak. When using sectoral shares as instruments the effect is still statistically significant and around $18 \%$ larger than the OLS coefficients. A 10 percentage point increase in the change of the employment rate raises the pro-EU voting index by roughly 5 points (column (5)). These results indicate that bad labor market conditions translate into voting for parties campaigning on an anti-EU platform.

I also estimate the effect on turnout as participating in European Parliament elections may be another way to express dismay or approval of the EU (see Guiso et al. (2017)). I do not find any statistically significant effect on turnout in the unconditional model (Table A22, column (1)). When adding region and year fixed effects (column (2)) as well as country specific linear time trends (column (3)) the effects become highly statistically significant (a 10 percentage point increase in the change of the employment rate corresponds to a increase in turnout of roughly 2 percentage points). While the 2SLS estimate using the Bartik instrument is negatively significant the estimate using sectoral shares as instruments is positively significant. These results thus only provide suggestive evidence that the decision to turnout at European Parliament elections is driven by labor market conditions.

\section{Conclusion}

This paper has shown that regional employment changes affect support for the EU by affecting voting behavior and attitudes. Applying both panel and instrumental variable estimation strategies I find that a decrease in the change of the employment rate is associated with voting for more anti-EU parties and a deterioration of the image of the EU, perceived benefit from the EU and evaluation of the EU membership of one's country. These effects are particularly strong for 'losers of globalization', i.e. unskilled and unemployed people. I also find that the effect of employment changes on the image of the EU is most pronounced for unskilled workers living in regions exposed to high EU migration.

In estimating these effects I take advantage of Eurobarometer survey data which allows linking respondents to their region of residence as well as regional employment data. My analyses are thus based on a novel panel covering roughly 260 European regions over 20 years. In addition, I introduce a Bartik-style instrument, which exploits variation in industry specializations across regions in combination with Europe-wide sector-specific shocks. All different estimation approaches, including fixed effects models, lagged dependent variables and the IV model, confirm the relationship between labor market conditions and support for the EU. It is however difficult to determine the mechanisms underlying this effect. I provide some suggestive evidence that fear of EU migration may be a concern linking labor market conditions to attitudes toward the EU. Further research is however needed to better understand whether (low-skilled) EU migration is a real threat for low-skilled local workers and whether policies or communication strategies can mitigate this concern. 
In times of Brexit and the success of anti-EU parties in many European countries public support for the European endeavor is more important than ever to ensure the stability of the union. Policy makers should therefore emphasize the economic benefits from political and economic integration and aim at redistributing the gains from globalization. More generally, it is important to avoid that regions are left behind and policy makers thus have to tackle inequalities in labor market opportunities. The IMF concluded in its fiscal monitor that "excessive inequality can erode social cohesion, lead to political polarization, and ultimately lower economic growth" (IMF, 2017). The findings of this paper thus do not only have implications for the political future of the EU but also for its growth prospects. 


\section{A.7 Eurobarometer Survey Questions}

Benefit: Taking everything into consideration, would you say that (OUR COUNTRY) has on balance benefited or not from being a member of the European Union?

- 0: not benefited

- 1: benefited

\begin{tabular}{ccccc}
\hline Mean & Std. Dev. & Obs. & Period covered & Regions \\
\hline 0.44 & 0.50 & 546,291 & $2001-2014$ & 260 \\
\hline
\end{tabular}

Membership: Generally speaking, do you think that (OUR COUNTRY'S) membership of the European Union is ... ?

- 0: A bad thing

- 0: Neither good nor bad

- 1: A good thing

\begin{tabular}{ccccc}
\hline Mean & Std. Dev. & Obs. & Period covered & Regions \\
\hline 0.65 & 0.48 & 533,722 & $1994-2011$ & 260 \\
\hline
\end{tabular}

Image: In general, does the European Union conjure up for you a very positive, fairly positive, neutral, fairly negative or very negative image?

- 0: Very negative

- 0: Fairly negative

- 0: Neutral

- 1: Very positive

- 1: Fairly positive

\begin{tabular}{ccccc}
\hline Mean & Std. Dev. & Obs. & Period covered & Regions \\
\hline 0.55 & 0.49 & 567,567 & $1994-2011$ & 260 \\
\hline
\end{tabular}


Table A1: Summary statistics: Eurobarometer data (aggregated to regional level)

\begin{tabular}{lrrrrr}
\hline & Mean & SD & Min & Max & Obs \\
\hline Image & 43.60 & 15.40 & 0 & 93 & 2,827 \\
Benefit & 60.94 & 17.03 & 0 & 100 & 3,091 \\
Membership & 53.93 & 16.07 & 0 & 100 & 3,091 \\
EU Support Index & 56.90 & 14.82 & 0 & 100 & 2,151 \\
Trust national government & 36.36 & 17.02 & 0 & 100 & 3,014 \\
Trust national parliament & 38.99 & 19.53 & 0 & 100 & 3,014 \\
Trust EU Parliament & 60.53 & 17.32 & 0 & 100 & 3,014 \\
\hline
\end{tabular}

Table A2: Summary statistics: Eurobarometer data (individual-level data)

\begin{tabular}{lrrrrr}
\hline & Mean & SD & Min & Max & Obs \\
\hline Age & 46.85 & 18.24 & 15 & 99 & 805,578 \\
Gender & 1.54 & 0.50 & 1 & 2 & 832,290 \\
Education & 2.19 & 0.89 & 1 & 4 & 749,618 \\
Unemployed & 0.07 & 0.26 & 0 & 1 & 833,226 \\
Low-skilled & 0.26 & 0.44 & 0 & 1 & 689,023 \\
\hline
\end{tabular}


Figure A1: Evolution of image of EU, benefit from EU and evaluation of EU membership over time
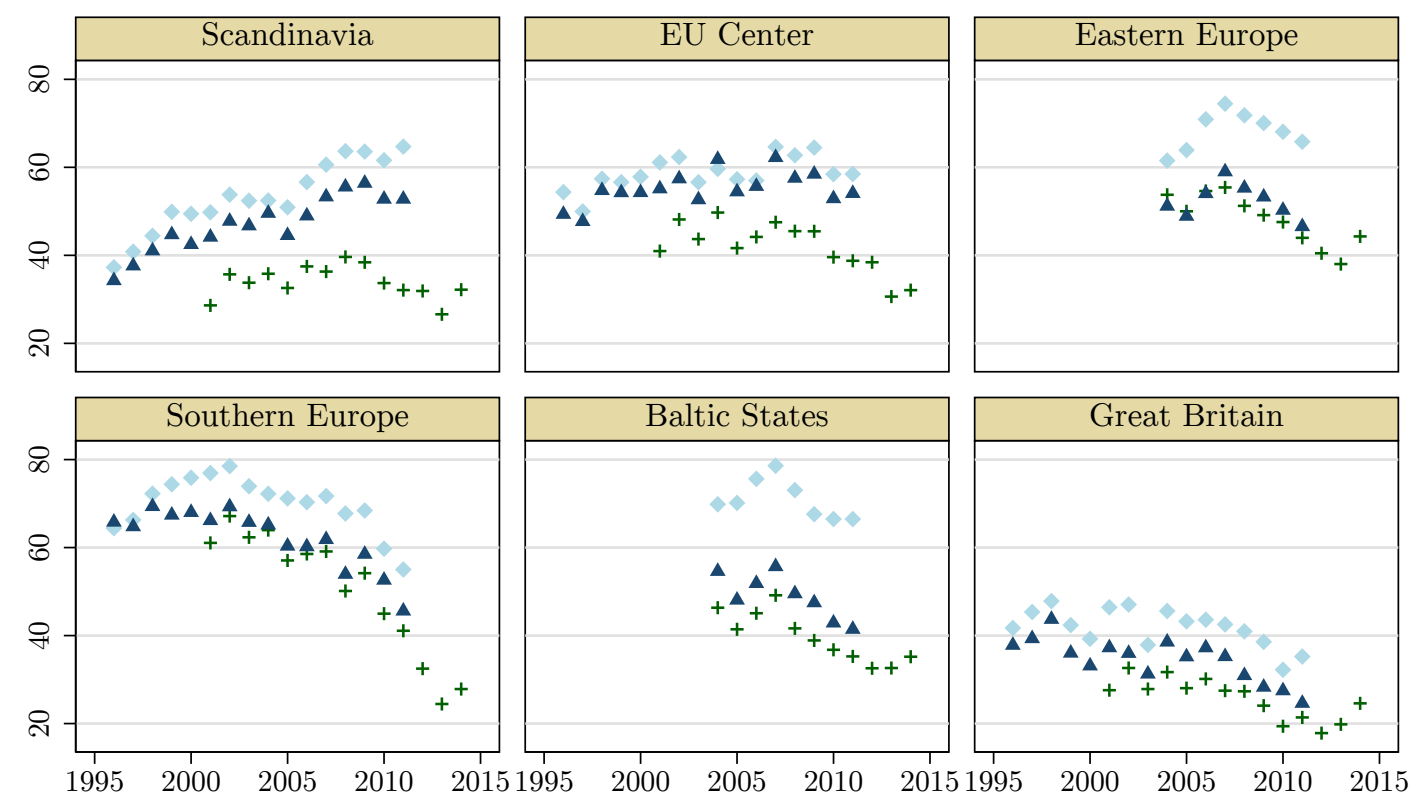

Year

\begin{tabular}{|l}
+ Image of EU \\
$\Delta$ EU Membership
\end{tabular}

Scandinavia: Denmark, Finland and Sweden. EU Center: Austria, Belgium, Germany, France, Luxembourg and Netherlands. Eastern Europe: Bulgaria, Czech Rep., Croatia, Poland, Romania, Slovakia, Slovenia. Southern Europe: Greece, Spain, Italy and Portugal, Baltic States: Estonia, Latvia and Lithuania. 


\section{A.8 Sources Voting Data}

Table A3: Sources: European Parliament Election results 2014

\begin{tabular}{ll}
\hline Austria & http://euwahl2014.bmi.gv.at \\
Belgium & http://polling2014.belgium.be \\
Bulgaria & http://results.cik.bg/ep2014 \\
Croatia & http://www.izbori.hr \\
Cyprus & http://www.europarl.europa.eu/elections2014-results \\
Czech Republic & http://www.volby.cz \\
Denmark & http://dst.dk/valg \\
Estonia & http://ep2014.vvk.ee/voting-results-en.html \\
Finland & http://stat.fi/tup/tilastotietokannat/index_en.html \\
France & http://www.interieur.gouv.fr/Elections/Les-resultats/Europeennes \\
Germany & http://www.bundeswahlleiter.de/europawahlen/2014.html \\
Greece & http://www.ypes.gr/en/Elections/ \\
Hungary & http://www.valasztas.hu/hu/ep2014/ \\
Ireland & http://electionsireland.org/results/europe/index.cfm \\
Italy & http://elezionistorico.interno.it/ \\
Latvia & http://www.europarl.europa.eu/elections2014-results \\
Lithuania & http://www.europarl.europa.eu/elections2014-results \\
Luxembourg & http://www.europarl.europa.eu/elections2014-results \\
Netherlands & http://www.nlverkiezingen.com/EP2014P.html \\
Poland & http://pe2014.pkw.gov.pl/pl/ \\
Portugal & http://www.eleicoes.mai.gov.pt \\
Romania & http://www.roaep.ro/bec_europ2014 \\
Slovakia & http://volby.statistics.sk/ep/ep2014/ \\
Slovenia & http://www.dvk-rs.si/index.php/si/volitve/evropski-parlament \\
Sweden & http://www.val.se/val/ep2014/slutresultat/E/rike/index.html \\
Spain & http://www.infoelectoral.mir.es/infoelectoral/min/ \\
United Kingdom & http://www.bbc.com/news/politics/eu-regions/E15000004 \\
\hline
\end{tabular}


Table A4: Summary statistics: voting in European Parliament elections

\begin{tabular}{lrrrrr}
\hline & Mean & SD & Min & Max & Obs \\
\hline Pro EU Voting & 56.68 & 14.58 & 0 & 100 & 819 \\
Turnout & 46.67 & 17.70 & 0 & 94 & 740 \\
\hline
\end{tabular}

Table A5: Correlation between different aspects of euroscepticism

\begin{tabular}{lcccc}
\hline & Pro EU Score (EED) & Membership & Benefit & Image \\
\hline Pro EU Score (EED) & 1.00 & & & \\
Membership & 0.44 & 1.00 & & \\
Benefit & 0.34 & 0.83 & 1.00 & \\
Image & 0.40 & 0.77 & 0.74 & 1.00 \\
\hline
\end{tabular}




\section{A.9 Employment data}

Figure A2: Histogram of change of employment rate

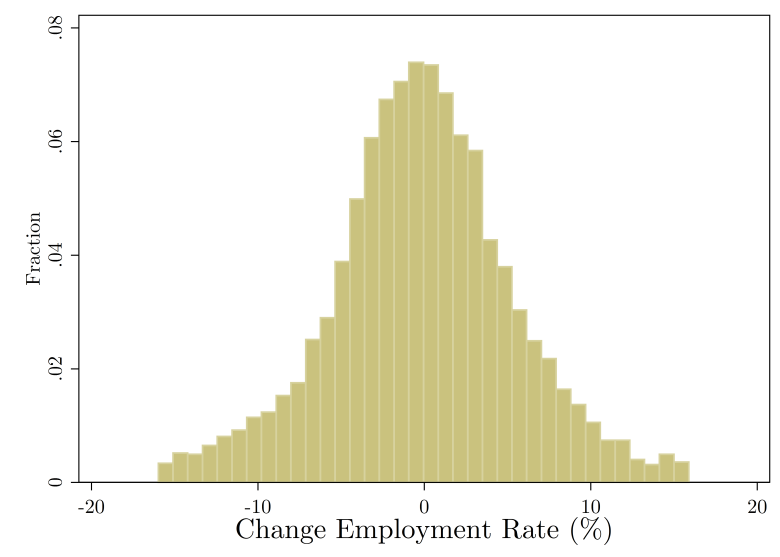

Table A6: Summary statistics of change in employment rate

\begin{tabular}{ccccc}
\hline Mean & Std. Dev. & Obs. & Period covered & Regions \\
\hline 0.015 & 0.08 & 6,955 & $1980-2014$ & 285 \\
\hline
\end{tabular}


Figure A3: Evolution of change in employment rate over time

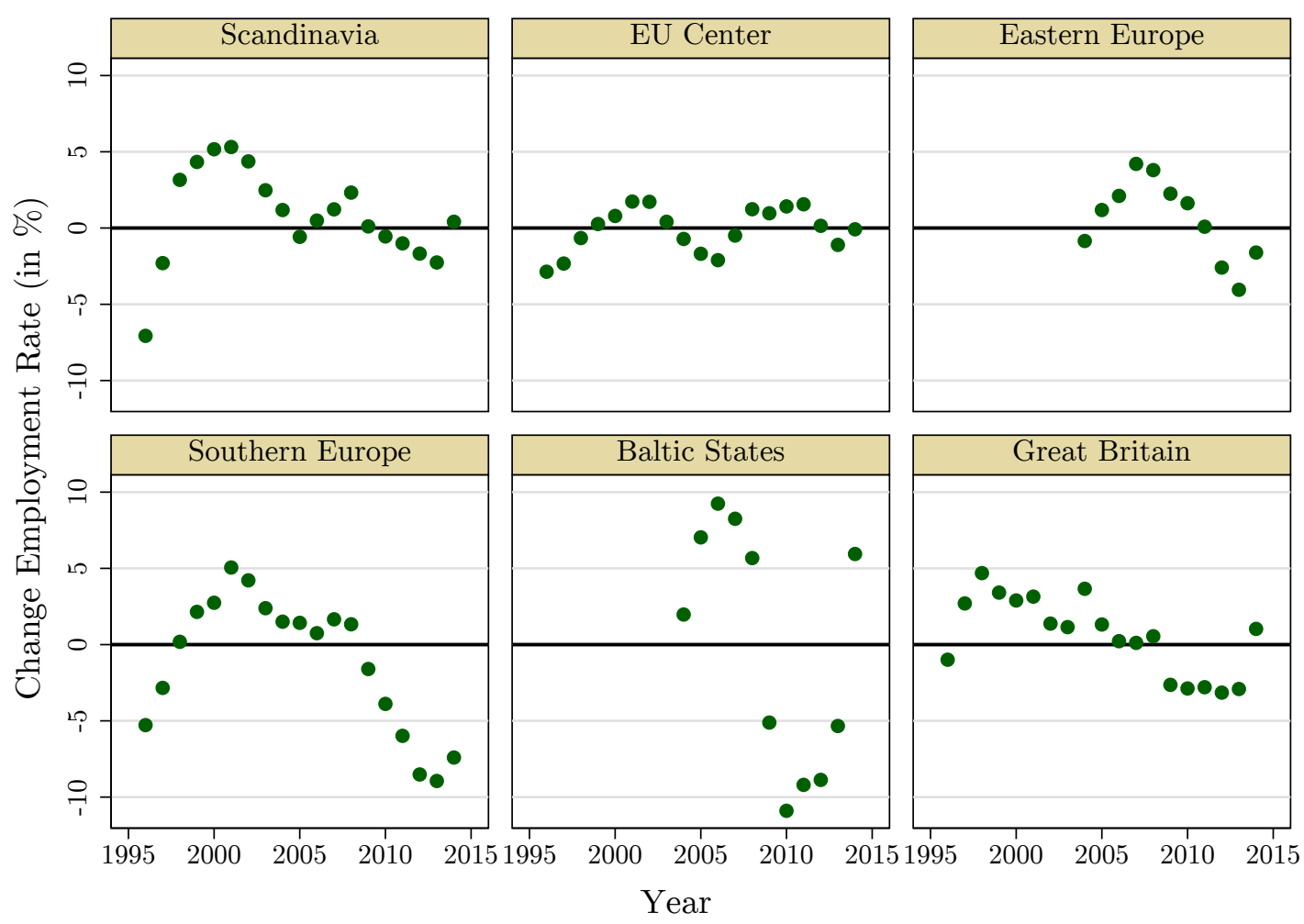

Scandinavia: Denmark, Finland and Sweden. EU Center: Austria, Belgium, Germany, France, Luxembourg and Netherlands. Eastern Europe: Bulgaria, Czech Rep., Croatia, Poland, Romania, Slovakia, Slovenia. Southern Europe: Greece, Spain, Italy and Portugal, Baltic States: Estonia, Latvia and Lithuania. 
Table A7: Summary Statistics: employment and migration data

\begin{tabular}{lrrrrr}
\hline & Mean & SD & Min & Max & Obs \\
\hline$\Delta$ Employment (\%) & -0.13 & 5.47 & -16 & 16 & 4,450 \\
Share EU migrants & 3.41 & 6.07 & 0 & 73 & 1,326 \\
Low-skilled EU/Low-skilled Home & 3.84 & 6.30 & 0 & 67 & 1,146 \\
\hline
\end{tabular}


A.10 Robustness Checks 
Table A8: Bias corrected fixed effect estimator

\begin{tabular}{|c|c|c|c|c|c|c|c|c|c|}
\hline & \multicolumn{3}{|c|}{ Image } & \multicolumn{3}{|c|}{ Benefit } & \multicolumn{3}{|c|}{ Membership } \\
\hline & (1) & (2) & (3) & (4) & (5) & (6) & (7) & (8) & (9) \\
\hline & $\mathrm{FE}$ & CFE-AH & CFE-AB & FE & CFE-AH & CFE-AB & FE & CFE-AH & CFE-AB \\
\hline$\Delta$ Employment $(\%)$ & $\begin{array}{c}0.3171^{* * *} \\
(0.0580)\end{array}$ & $\begin{array}{c}0.3049^{* * *} \\
(0.0303)\end{array}$ & $\begin{array}{c}0.2940^{* * *} \\
(0.0304)\end{array}$ & $\begin{array}{c}0.2135^{* * *} \\
(0.0650)\end{array}$ & $\begin{array}{c}0.1951^{* * *} \\
(0.0578)\end{array}$ & $\begin{array}{c}0.1919^{* * *} \\
(0.0571)\end{array}$ & $\begin{array}{c}0.1222^{* *} \\
(0.0601)\end{array}$ & $\begin{array}{l}0.1102^{*} \\
(0.0575)\end{array}$ & $\begin{array}{l}0.1117^{*} \\
(0.0571)\end{array}$ \\
\hline Image $_{t-5}$ & $\begin{array}{c}0.2306^{* * *} \\
(0.0356)\end{array}$ & $\begin{array}{c}0.3283^{* * *} \\
(0.0231)\end{array}$ & $\begin{array}{c}0.3318^{* * *} \\
(0.0218)\end{array}$ & & & & & & \\
\hline Benefit $_{t-5}$ & & & & $\begin{array}{c}0.3172^{* * *} \\
(0.0360)\end{array}$ & $\begin{array}{c}0.4207^{* * *} \\
(0.0125)\end{array}$ & $\begin{array}{c}0.4168^{* * *} \\
(0.0121)\end{array}$ & & & \\
\hline Membershipt-5 & & & & & & & $\begin{array}{c}0.3066^{* * *} \\
(0.0371)\end{array}$ & $\begin{array}{c}0.4071^{* * *} \\
(0.0137)\end{array}$ & $\begin{array}{c}0.4060^{* * *} \\
(0.0137)\end{array}$ \\
\hline Region FE & $\checkmark$ & $\checkmark$ & $\checkmark$ & $\checkmark$ & $\checkmark$ & $\checkmark$ & $\checkmark$ & $\checkmark$ & $\checkmark$ \\
\hline Year FE & $\checkmark$ & $\checkmark$ & $\checkmark$ & $\checkmark$ & $\checkmark$ & $\checkmark$ & $\checkmark$ & $\checkmark$ & $\checkmark$ \\
\hline $\mathrm{N}$ & 2,429 & 2,429 & 2,429 & 2,706 & 2,706 & 2,706 & 2,706 & 2,706 & 2,706 \\
\hline Mean DV & 43.73 & 43.73 & 43.73 & 46.31 & 45.41 & 45.41 & 46.31 & 45.41 & 45.41 \\
\hline
\end{tabular}

Bias corrected LSDV dynamic panel data estimator. Columns (1), (4) and (7) present results using a fixed effect estimator. In columns (2), (5) and (8) bias correction is initialized by Anderson-Hsiao estimator and in columns (3), (6) and (9) by Arellano and Bond estimator. Image, Benefit and Membership are outcome variables based on Eurobarometer survey questions and are coded to lie between 0 and 100. Change in employment rate is computed over five years. Bootstrapped standard errors. *** $\mathrm{p}<0.01,{ }^{* *} \mathrm{p}<0.05,{ }^{*} \mathrm{p}<0.1$ 
Figure A4: Emplyoment change over various years

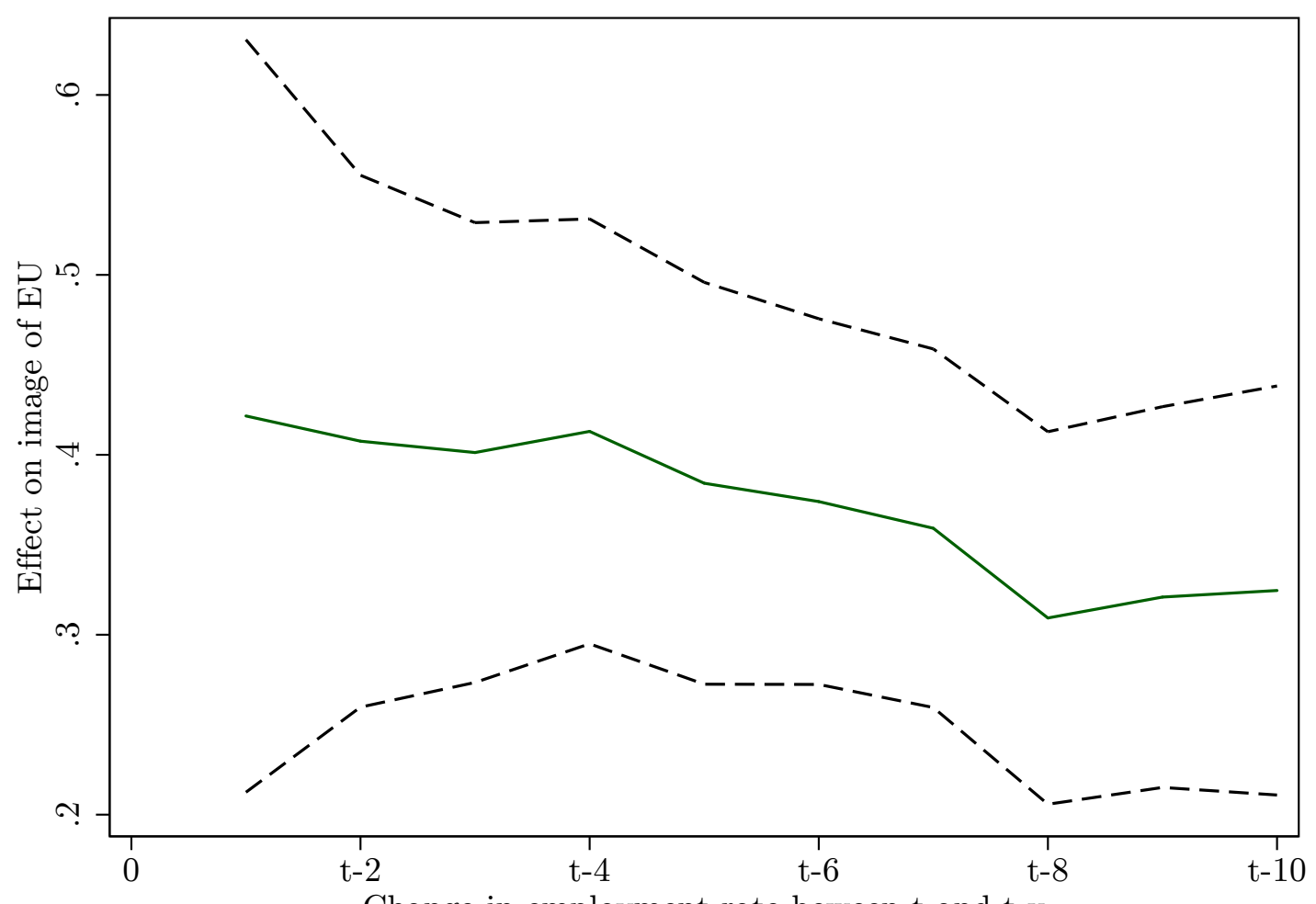

Coefficients from baseline OLS regression (including region and year FE) and 95\% confidence bands for different time horizon of explanatory variable. 
Table A9: Effect of binary employment changes on attitudes toward the EU

\begin{tabular}{lccc}
\hline & $(1)$ & $(2)$ & $(3)$ \\
& Image & Benefit & Membership \\
\hline$\Delta$ Employment (Binary) & $2.9088^{* * *}$ & $2.1608^{* * *}$ & 1.0779 \\
& $(0.6285)$ & $(0.7053)$ & $(0.7046)$ \\
\hline Year FE & $\checkmark$ & $\checkmark$ & $\checkmark$ \\
Region FE & $\checkmark$ & $\checkmark$ & $\checkmark$ \\
adj. R ${ }^{2}$ & 0.63 & 0.62 & 0.60 \\
$\mathrm{~N}$ & 2,668 & 2,950 & 2,950 \\
Cluster & 265 & 264 & 264 \\
Mean DV & 43.86 & 61.01 & 53.92 \\
\hline
\end{tabular}

OLS estimations. Image, Benefit and Membership are outcome variables based on Eurobarometer survey questions and are coded to lie between 0 and 100 . Change in employment rate is binary ( 1 if positive over past 5 years, 0 if negative over past five years). Standard errors (clustered by region) in parentheses. *** $\mathrm{p}<0.01,{ }^{* *} \mathrm{p}<0.05,{ }^{*} \mathrm{p}<0.1$. 
Table A10: Effect of employment changes on attitudes toward the EU

\begin{tabular}{|c|c|c|c|}
\hline & $\begin{array}{c}(1) \\
\text { Image }\end{array}$ & $\begin{array}{c}(2) \\
\text { Benefit }\end{array}$ & $\begin{array}{c}(3) \\
\text { Membership }\end{array}$ \\
\hline$\Delta$ Absolute Employment $(\%)$ & $\begin{array}{c}0.4487^{* * *} \\
(0.0611)\end{array}$ & $\begin{array}{c}0.4256^{* * *} \\
(0.0579)\end{array}$ & $\begin{array}{c}0.2211^{* * *} \\
(0.0601)\end{array}$ \\
\hline Change Active Population (\%) & $\begin{array}{l}-2.8778 \\
(7.2219)\end{array}$ & $\begin{array}{l}12.0728 \\
(9.8012)\end{array}$ & $\begin{array}{l}-4.0525 \\
(9.4951)\end{array}$ \\
\hline Year FE & $\checkmark$ & $\checkmark$ & $\checkmark$ \\
\hline Region FE & $\checkmark$ & $\checkmark$ & $\checkmark$ \\
\hline adj. $R^{2}$ & 0.63 & 0.64 & 0.60 \\
\hline $\mathrm{N}$ & 2,715 & 2,980 & 2,980 \\
\hline Cluster & 265 & 264 & 264 \\
\hline Mean DV & 43.73 & 61.04 & 53.91 \\
\hline
\end{tabular}

OLS estimations. Image, Benefit and Membership are outcome variables based on Eurobarometer survey questions and are coded to lie between 0 and 100. Absolute change in employment is computed over five years. Additional control variable is change in active population over the same time. Standard errors (clustered by region) in parentheses. ${ }^{* * *} \mathrm{p}<0.01,{ }^{* *} \mathrm{p}<0.05,{ }^{*} \mathrm{p}<0.1$.

Table A11: Effect of employment changes on attitudes toward the EU

\begin{tabular}{lccc}
\hline & $(1)$ & $(2)$ & $(3)$ \\
& Image & Benefit & Membership \\
\hline$\Delta$ Employment (\%) & $0.1701^{* *}$ & $0.2161^{* *}$ & $0.1615^{*}$ \\
& $(0.0788)$ & $(0.1027)$ & $(0.0923)$ \\
Employment Rate (\%) & $0.5543^{* * *}$ & $0.3053^{*}$ & 0.0778 \\
& $(0.1180)$ & $(0.1816)$ & $(0.1523)$ \\
\hline Year FE & $\checkmark$ & $\checkmark$ & $\checkmark$ \\
Region FE & $\checkmark$ & $\checkmark$ & $\checkmark$ \\
adj. R & 0.64 & 0.63 & 0.60 \\
$\mathrm{~N}$ & 2,668 & 2,950 & 2,950 \\
Cluster & 265 & 264 & 264 \\
Mean DV & 43.86 & 61.01 & 53.92 \\
\hline
\end{tabular}

OLS estimations. Image, Benefit and Membership are outcome variables based on Eurobarometer survey questions and are coded to lie between 0 and 100. Change in employment rate is computed over five years. Level of employment rate is added as additional control. Standard errors (clustered by region) in parentheses. ${ }^{* * *} \mathrm{p}<0.01,{ }^{* *} \mathrm{p}<0.05,{ }^{*} \mathrm{p}<0.1$. 
Table A12: Effect of employment changes on attitudes toward the EU

\begin{tabular}{lccc}
\hline & $(1)$ & $(2)$ & $(3)$ \\
& EU Support Index & EU Support Index & EU Support Index \\
\hline$\Delta$ Employment (\%) & $0.3102^{* * *}$ & $0.2422^{* * *}$ & $0.4098^{* * *}$ \\
& $(0.0768)$ & $(0.0682)$ & $(0.1140)$ \\
EU Support Index 5 -5 & & & -0.0482 \\
& & & $(0.0661)$ \\
\hline Year FE & $\checkmark$ & $\checkmark$ & $\checkmark$ \\
Region FE & $\checkmark$ & $\checkmark$ & $\checkmark$ \\
Country FE x Year & & $\checkmark$ & 0.68 \\
adj. R & & 0.67 & 936 \\
N & 0.63 & 2,030 & 190 \\
Cluster & 2,030 & 263 & 44.33 \\
Mean DV & 263 & 46.45 & \\
\hline
\end{tabular}

OLS estimations. Change in employment rate is computed over five years. EU Support index is first principal component of image, benefit and membership variables and scaled to lie between 0 and 100 . Column (3) includes fifth lag of EU support index as control variable. Standard errors (clustered by region) in parentheses. ${ }^{* * *} \mathrm{p}<0.01,{ }^{* *} \mathrm{p}<0.05,{ }^{*} \mathrm{p}<0.1$.

Table A13: Effect of employment changes on attitudes toward the EU

\begin{tabular}{lcccc}
\hline & $(1)$ & $(2)$ & $(3)$ & $\begin{array}{c}(4) \\
\text { Trust }\end{array}$ \\
& Image & Benefit & Membership & EU Parliament \\
\hline$\Delta$ Employment (\%) & $0.1686^{* * *}$ & $0.2010^{* *}$ & 0.0731 & $0.1722^{* * *}$ \\
& $(0.0491)$ & $(0.0783)$ & $(0.0725)$ & $(0.0542)$ \\
Trust in national government & 0.0083 & 0.0024 & -0.0471 & -0.0564 \\
& $(0.0419)$ & $(0.0445)$ & $(0.0442)$ & $(0.0412)$ \\
Trust in national parliament & $0.3828^{* * *}$ & $0.3429^{* * *}$ & $0.3535^{* * *}$ & $0.5824^{* * *}$ \\
& $(0.0412)$ & $(0.0443)$ & $(0.0422)$ & $(0.0424)$ \\
\hline Year FE & $\checkmark$ & $\checkmark$ & $\checkmark$ & $\checkmark$ \\
Region FE & $\checkmark$ & $\checkmark$ & $\checkmark$ & $\checkmark$ \\
adj. R ${ }^{2}$ & 0.72 & 0.69 & 0.69 & 0.73 \\
N & 2,668 & 2,213 & 2,213 & 2,851 \\
Cluster & 265 & 263 & 263 & 265 \\
Mean DV & 43.86 & 62.67 & 54.44 & 54.44 \\
\hline
\end{tabular}

OLS estimations. Image, Benefit and Membership are outcome variables based on Eurobarometer survey questions and are coded to lie between 0 and 100. Change in employment rate is computed over five years. Additional controls include trust in national government and trust in national parliament. Standard errors (clustered by region) in parentheses. ${ }^{* * *} \mathrm{p}<0.01,{ }^{*} \mathrm{p}<0.05,{ }^{*} \mathrm{p}<0.1$. 
Table A14: Effect of employment changes on attitudes toward the EU including control variables

\begin{tabular}{|c|c|c|c|c|c|c|c|c|c|}
\hline & \multicolumn{3}{|c|}{ Image } & \multicolumn{3}{|c|}{ Benefit } & \multicolumn{3}{|c|}{ Membership } \\
\hline & $(1)$ & $(2)$ & (3) & (4) & $(5)$ & (6) & (7) & (8) & (9) \\
\hline$\Delta$ Employment $(\%)$ & $\begin{array}{c}0.3346^{* * *} \\
(0.0617)\end{array}$ & $\begin{array}{c}0.3520^{* * *} \\
(0.0627)\end{array}$ & $\begin{array}{c}0.2972^{* * *} \\
(0.0657)\end{array}$ & $\begin{array}{c}0.3168^{* * *} \\
(0.0864)\end{array}$ & $\begin{array}{c}0.3561^{* * *} \\
(0.0870)\end{array}$ & $\begin{array}{c}0.2971^{* * *} \\
(0.0906)\end{array}$ & $\begin{array}{c}0.1642^{* *} \\
(0.0798)\end{array}$ & $\begin{array}{c}0.2082^{* *} \\
(0.0820)\end{array}$ & $\begin{array}{r}0.1836^{* *} \\
(0.0867)\end{array}$ \\
\hline Year FE & $\checkmark$ & $\checkmark$ & $\checkmark$ & $\checkmark$ & $\checkmark$ & $\checkmark$ & $\checkmark$ & $\checkmark$ & $\checkmark$ \\
\hline Region FE & $\checkmark$ & $\checkmark$ & $\checkmark$ & $\checkmark$ & $\checkmark$ & $\checkmark$ & $\checkmark$ & $\checkmark$ & $\checkmark$ \\
\hline Education Controls & $\checkmark$ & $\checkmark$ & $\checkmark$ & $\checkmark$ & $\checkmark$ & $\checkmark$ & $\checkmark$ & $\checkmark$ & $\checkmark$ \\
\hline Demographic Controls & & $\checkmark$ & $\checkmark$ & & $\checkmark$ & $\checkmark$ & & $\checkmark$ & $\checkmark$ \\
\hline Migration Control & & & $\checkmark$ & & & $\checkmark$ & & & $\checkmark$ \\
\hline $\operatorname{adj} . R^{2}$ & 0.64 & 0.65 & 0.65 & 0.65 & 0.65 & 0.66 & 0.65 & 0.65 & 0.66 \\
\hline $\mathrm{N}$ & 2,588 & 2,588 & 2,552 & 2,118 & 2,118 & 2,083 & 2,118 & 2,118 & 2,083 \\
\hline Cluster & 261 & 261 & 261 & 259 & 259 & 259 & 259 & 259 & 259 \\
\hline Mean DV & 43.91 & 43.91 & 43.71 & 46.59 & 46.59 & 46.35 & 46.59 & 46.59 & 46.35 \\
\hline
\end{tabular}

OLS estimations. Image, Benefit and Membership are outcome variables based on Eurobarometer survey questions and are coded to lie between 0 and 100. Change in employment rate is computed over five years. Education controls include primary education (in\%), secondary education (in\%) and tertiary education (in\%). Demographic controls include median age and old age ratio (65 and above compared to 15-65 year olds). Migration is crude rate of net migration plus adjustment. Standard errors (clustered by region) in parentheses. ${ }^{* * *} \mathrm{p}<0.01,{ }^{* *} \mathrm{p}<0.05,{ }^{*} \mathrm{p}<0.1$. 
Table A15: Effect of employment changes on attitudes toward the EU: individual-level observations

\begin{tabular}{|c|c|c|c|c|c|c|c|c|c|}
\hline & \multicolumn{3}{|c|}{ Image } & \multicolumn{3}{|c|}{ Benefit } & \multicolumn{3}{|c|}{ Membership } \\
\hline & $(1)$ & $(2)$ & (3) & (4) & $(5)$ & $(6)$ & $(7)$ & (8) & (9) \\
\hline$\Delta$ Employment $(\%)$ & $\begin{array}{c}0.2636^{* * *} \\
(0.0734)\end{array}$ & $\begin{array}{c}0.2831^{* * * *} \\
(0.0717)\end{array}$ & $\begin{array}{c}0.1662^{* * * *} \\
(0.0551)\end{array}$ & $\begin{array}{c}0.3425^{* * *} \\
(0.0893)\end{array}$ & $\begin{array}{c}0.3612^{\text {*** }} \\
(0.0864)\end{array}$ & $\begin{array}{c}0.2816^{* * *} \\
(0.0588)\end{array}$ & $\begin{array}{c}0.2141^{* *} \\
(0.0842)\end{array}$ & $\begin{array}{c}0.2151^{* *} \\
(0.0858)\end{array}$ & $\begin{array}{c}0.1204^{* *} \\
(0.0546)\end{array}$ \\
\hline Year FE & $\checkmark$ & $\checkmark$ & $\checkmark$ & $\checkmark$ & $\checkmark$ & $\checkmark$ & $\checkmark$ & $\checkmark$ & $\checkmark$ \\
\hline Region FE & $\checkmark$ & $\checkmark$ & $\checkmark$ & $\checkmark$ & $\checkmark$ & $\checkmark$ & $\checkmark$ & $\checkmark$ & $\checkmark$ \\
\hline Ind. Controls & & $\checkmark$ & $\checkmark$ & & $\checkmark$ & $\checkmark$ & & $\checkmark$ & $\checkmark$ \\
\hline Country FE x Year & & & $\checkmark$ & & & $\checkmark$ & & & $\checkmark$ \\
\hline $\operatorname{adj} . R^{2}$ & 0.06 & 0.08 & 0.09 & 0.10 & 0.13 & 0.13 & 0.07 & 0.10 & 0.11 \\
\hline $\mathrm{N}$ & 520,233 & 422,610 & 422,610 & 513,015 & 450,974 & 450,974 & 544,846 & 476,720 & 476,720 \\
\hline Cluster & 265 & 265 & 265 & 264 & 264 & 264 & 264 & 264 & 264 \\
\hline Mean DV & 45.34 & 45.79 & 45.79 & 61.25 & 61.09 & 61.09 & 54.91 & 54.96 & 54.96 \\
\hline
\end{tabular}

OLS estimations. Image, Benefit and Membership are outcome variables based on Eurobarometer survey questions and are coded to lie between 0 and 100. Change in employment rate is computed over five years. Individual level control variables include age, gender and education. Estimation sample based on individual level observations. Standard errors (clustered by region) in parentheses. ${ }^{* * *} \mathrm{p}<0.01,{ }^{* *} \mathrm{p}<0.05,{ }^{*} \mathrm{p}<0.1$. 
Table A16: Effect of employment changes on attitudes toward the EU: logit estimations

\begin{tabular}{lccc}
\hline & $\begin{array}{c}(1) \\
\text { Image }\end{array}$ & $\begin{array}{c}(2) \\
\text { Benefit }\end{array}$ & $\begin{array}{c}(3) \\
\text { Membership }\end{array}$ \\
\hline & & & \\
$\Delta$ Employment (\%) & $0.0108^{* * * *}$ & $0.0179^{* * *}$ & $0.0094^{* *}$ \\
& $(0.0031)$ & $(0.0045)$ & $(0.0038)$ \\
\hline Year FE & $\checkmark$ & $\checkmark$ & $\checkmark$ \\
Region FE & $\checkmark$ & $\checkmark$ & $\checkmark$ \\
Pseudo R & 0.04 & 0.08 & 0.05 \\
N & 520,233 & 513,015 & 544,846 \\
Cluster & 265 & 264 & 264 \\
Mean DV & 44.30 & 65.36 & 55.49 \\
\hline
\end{tabular}

Logit estimations. Image, Benefit and Membership are outcome variables based on Eurobarometer survey questions and are coded to lie between 0 and 100. Change in employment rate is computed over five years. Standard errors (clustered by region) in parentheses. ${ }^{* * *} \mathrm{p}<0.01,{ }^{* *} \mathrm{p}<0.05$, $* \mathrm{p}<0.1$. 
Table A17: Effect of employment changes on attitudes toward the EU

\begin{tabular}{|c|c|c|c|c|c|c|}
\hline & \multicolumn{2}{|c|}{ Image } & \multicolumn{2}{|c|}{ Benefit } & \multicolumn{2}{|c|}{ Membership } \\
\hline & (1) & $(2)$ & (3) & $(4)$ & $(5)$ & (6) \\
\hline & Change $<0$ & Change $>0$ & Change $<0$ & Change $>0$ & Change $<0$ & Change $>0$ \\
\hline$\Delta$ Employment $(\%)$ & $\begin{array}{c}0.8481^{* * *} \\
(0.1500)\end{array}$ & $\begin{array}{l}-0.1730 \\
(0.1245)\end{array}$ & $\begin{array}{c}0.5011^{* * *} \\
(0.1869)\end{array}$ & $\begin{array}{c}0.0616 \\
(0.1163)\end{array}$ & $\begin{array}{c}0.5138^{* * *} \\
(0.1731)\end{array}$ & $\begin{array}{c}0.0521 \\
(0.1095)\end{array}$ \\
\hline Year FE & $\checkmark$ & $\checkmark$ & $\checkmark$ & $\checkmark$ & $\checkmark$ & $\checkmark$ \\
\hline Region FE & $\checkmark$ & $\checkmark$ & $\checkmark$ & $\checkmark$ & $\checkmark$ & $\checkmark$ \\
\hline adj. $R^{2}$ & 0.62 & 0.70 & 0.58 & 0.69 & 0.62 & 0.64 \\
\hline $\mathrm{N}$ & 1,320 & 1,348 & 1,380 & 1,570 & 1,380 & 1,570 \\
\hline Cluster & 233 & 244 & 235 & 241 & 235 & 241 \\
\hline Mean DV & 40.72 & 46.94 & 58.07 & 63.60 & 52.13 & 55.49 \\
\hline
\end{tabular}

OLS estimations. Image, Benefit and Membership are outcome variables based on Eurobarometer survey questions and are coded to lie between 0 and 100. Change in employment rate is computed over five years. Estimations for sub-samples. Columns (1), (3) and (5) focus on regions that experienced a negative change in the employment rate over past five years and columns (2), (4) and (6) focus on regions that experienced a positive change in the employment rate over past 5 years. Standard errors (clustered by region) in parentheses. ${ }^{* * *} \mathrm{p}<0.01,{ }^{* *} \mathrm{p}<0.05,{ }^{*} \mathrm{p}<0.1$. 
Figure A5: Country-group-specific effect heterogeneity

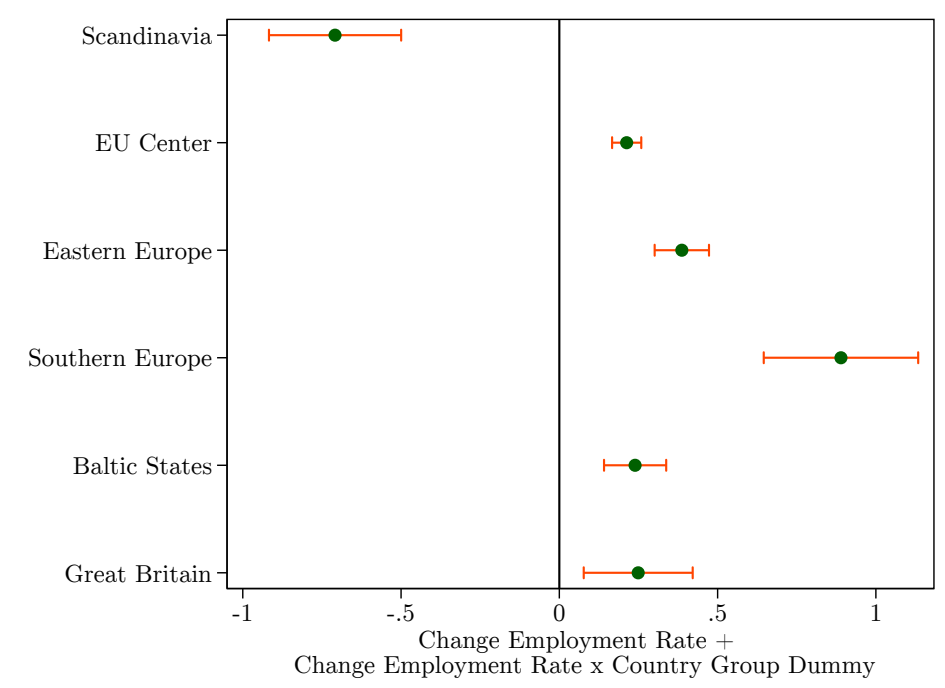

Interaction coefficients from fixed effect regressions of change in employment rate on image outcome including country group and year fixed effects and interactions between country dummies and change in employment rate. Figure shows base effect of change employment rate plus interaction effect. Base category is EU Center.

Figure A6: Country-specific effect heterogeneity

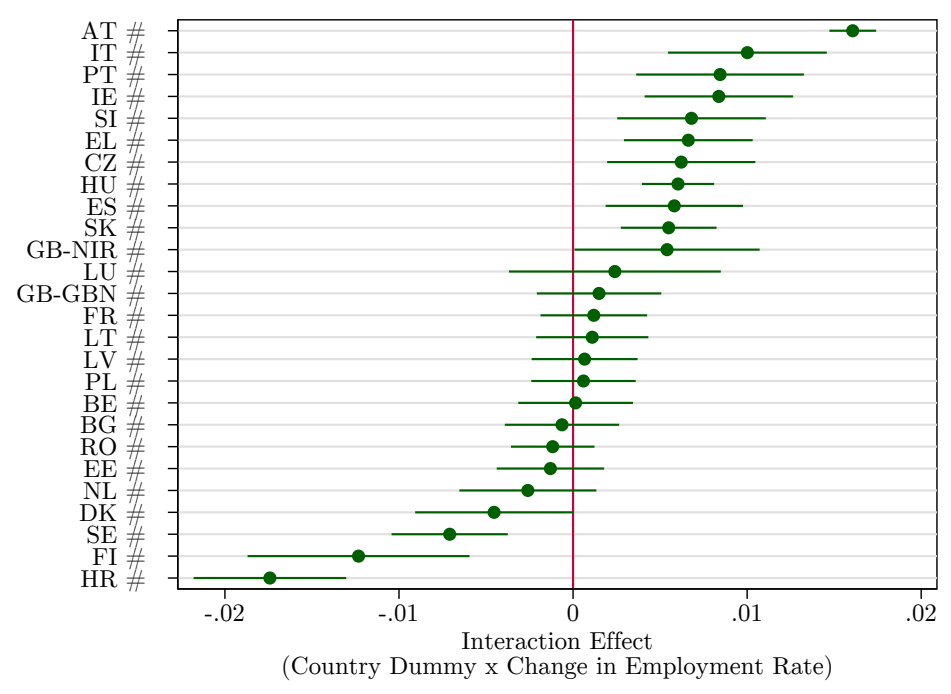

Interaction coefficients from fixed effect regressions of change in employment rate on image outcome including country and year fixed effects and interactions between country dummies and change in employment rate. Base category is Germany. 
Table A18: Effect of employment changes on attitudes toward the EU: interaction with non-EU migration

\begin{tabular}{|c|c|c|c|c|}
\hline & $\begin{array}{l}(1) \\
\text { Image }\end{array}$ & $\begin{array}{l}(2) \\
\text { Image }\end{array}$ & $\begin{array}{l}(3) \\
\text { Image }\end{array}$ & $\begin{array}{l}(4) \\
\text { Image }\end{array}$ \\
\hline$\Delta$ Employment Rate & $\begin{array}{c}0.2278 \\
(0.1543)\end{array}$ & $\begin{array}{c}0.2837^{* *} \\
(0.1322)\end{array}$ & $\begin{array}{c}0.3359 \\
(0.2176)\end{array}$ & $\begin{array}{c}0.3811 \\
(0.2324)\end{array}$ \\
\hline Share Non-EU migrants & $\begin{array}{l}14.2916 \\
(11.9242)\end{array}$ & $\begin{array}{l}18.9964 \\
(12.3160)\end{array}$ & & \\
\hline $\begin{array}{l}\Delta \text { Employment Rate } \times \\
\text { Share Non-EU migrants }\end{array}$ & $\begin{array}{c}0.2761 \\
(1.1828)\end{array}$ & $\begin{array}{c}0.1133 \\
(1.2014)\end{array}$ & & \\
\hline $\begin{array}{l}\text { Low-skilled } \times \Delta \text { Employment Rate } \times \\
\text { Share Non-EU migrants }\end{array}$ & & $\begin{array}{l}-1.2013 \\
(1.8053)\end{array}$ & & \\
\hline LS Non-EU/LS Home & & & $\begin{array}{c}20.6648 \\
(17.4045)\end{array}$ & $\begin{array}{c}9.6420 \\
(16.6549)\end{array}$ \\
\hline $\begin{array}{l}\Delta \text { Employment Rate } \times \\
\text { LS Non-EU/LS Home }\end{array}$ & & & $\begin{array}{l}-0.0949 \\
(1.8771)\end{array}$ & $\begin{array}{l}-0.3016 \\
(2.0650)\end{array}$ \\
\hline $\begin{array}{l}\text { Low-skilled } \times \Delta \text { Employment Rate } \times \\
\text { LS Non-EU/LS Home }\end{array}$ & & & & $\begin{array}{l}-1.1352 \\
(1.7791)\end{array}$ \\
\hline Region FE & $\checkmark$ & $\checkmark$ & $\checkmark$ & $\checkmark$ \\
\hline Year FE & $\checkmark$ & $\checkmark$ & $\checkmark$ & $\checkmark$ \\
\hline $\operatorname{adj} . R^{2}$ & 0.05 & 0.06 & 0.05 & 0.06 \\
\hline $\mathrm{N}$ & 278,413 & 218,374 & 244,857 & 193,280 \\
\hline Cluster & 166 & 166 & 162 & 162 \\
\hline Mean DV & 40.74 & 39.88 & 40.36 & 39.65 \\
\hline
\end{tabular}

OLS estimations. The image outcome variable is based on a Eurobarometer survey question and is coded to lie between 0 and 100. Change in employment rate is computed over five years. Standard errors (clustered by region) in parentheses. ${ }^{* * *} \mathrm{p}<0.01,{ }^{* *} \mathrm{p}<0.05,{ }^{*} \mathrm{p}<0.1$. 
Table A19: 2SLS estimations: effect of employment changes on attitudes toward the EU

\begin{tabular}{|c|c|c|c|c|c|c|}
\hline & \multicolumn{2}{|c|}{ Image } & \multicolumn{2}{|c|}{ Benefit } & \multicolumn{2}{|c|}{ Membership } \\
\hline & (1) & $(2)$ & (3) & (4) & $(5)$ & $(6)$ \\
\hline$\Delta$ Employment $(\%)$ & $\begin{array}{c}2.764^{* * *} \\
(0.412)\end{array}$ & $\begin{array}{c}3.548^{* * *} \\
(0.341)\end{array}$ & $\begin{array}{l}1.206 \\
(0.864)\end{array}$ & $\begin{array}{c}2.243^{* * *} \\
(0.447)\end{array}$ & $\begin{array}{c}4.244^{* *} \\
(1.681)\end{array}$ & $\begin{array}{c}1.822^{* * *} \\
(0.397)\end{array}$ \\
\hline Image $_{t-5}$ & $\begin{array}{c}0.535^{* * *} \\
(0.0477)\end{array}$ & $\begin{array}{l}-0.0632 \\
(0.0631)\end{array}$ & & & & \\
\hline Benefit $_{t-5}$ & & & $\begin{array}{c}0.576^{* * *} \\
(0.0328)\end{array}$ & $\begin{array}{c}0.181^{* * *} \\
(0.0529)\end{array}$ & & \\
\hline Membershipt-5 $_{\text {t }}$ & & & & & $\begin{array}{c}0.569^{* * *} \\
(0.0691)\end{array}$ & $\begin{array}{c}0.102^{*} \\
(0.0555)\end{array}$ \\
\hline Region FE & & $\checkmark$ & & $\checkmark$ & & $\checkmark$ \\
\hline $\mathrm{N}$ & 1,556 & 1,556 & 1,732 & 1,732 & 1,732 & 1,732 \\
\hline Cluster & 206 & 206 & 249 & 249 & 249 & 249 \\
\hline 1st stage F-Test & 59.24 & 77.18 & 7.07 & 31.76 & 7.91 & 33.05 \\
\hline Mean DV & 40.56 & 40.56 & 62.16 & 62.16 & 54.54 & 54.54 \\
\hline
\end{tabular}

2SLS estimations. Image, Benefit and Membership are outcome variables based on Eurobarometer survey questions and are coded to lie between 0 and 100. Change in employment rate is computed over five years. Kleibergen-Paap rk Wald F statistic reported. Standard errors (clustered by region) in parentheses. *** $\mathrm{p}<0.01,{ }^{* *} \mathrm{p}<0.05,{ }^{*} \mathrm{p}<0.1$. 
Table A20: 2SLS estimations: effect of employment changes on attitudes toward the EU. Own country excluded in calculation of Bartik instrument.

\begin{tabular}{|c|c|c|c|c|c|c|}
\hline & \multicolumn{2}{|c|}{ Image } & \multicolumn{2}{|c|}{ Benefit } & \multicolumn{2}{|c|}{ Membership } \\
\hline & (1) & $(2)$ & $(3)$ & (4) & (5) & (6) \\
\hline$\Delta$ Employment (\%) & $\begin{array}{l}1.430^{* *} \\
(0.566)\end{array}$ & $\begin{array}{c}3.520^{* * *} \\
(0.385)\end{array}$ & $\begin{array}{c}-3.292^{*} \\
(1.698)\end{array}$ & $\begin{array}{c}1.970^{* * *} \\
(0.296)\end{array}$ & $\begin{array}{c}1.402 \\
(0.966)\end{array}$ & $\begin{array}{c}1.559^{* * *} \\
(0.283)\end{array}$ \\
\hline Region FE & & $\checkmark$ & & $\checkmark$ & & $\checkmark$ \\
\hline $\mathrm{N}$ & 2,615 & 2,615 & 2,922 & 2,922 & 2,922 & 2,922 \\
\hline Cluster & 265 & 265 & 263 & 263 & 263 & 263 \\
\hline 1st stage F-Test & 27.52 & 57.31 & 10.03 & 71.29 & 10.03 & 71.29 \\
\hline Mean DV & 43.51 & 43.51 & 60.89 & 60.89 & 53.81 & 53.81 \\
\hline
\end{tabular}

2SLS estimations. Kleibergen-Paap rk Wald F statistic reported. Standard errors (clustered by region) in parentheses. ${ }^{* * *} \mathrm{p}<0.01,{ }^{* *} \mathrm{p}<0.05,{ }^{*} \mathrm{p}<0.1$.

Table A21: 2SLS estimations with individual-level data: effect of employment changes on attitudes toward the EU

\begin{tabular}{|c|c|c|c|c|c|c|}
\hline & \multicolumn{2}{|c|}{ Image } & \multicolumn{2}{|c|}{ Benefit } & \multicolumn{2}{|c|}{ Membership } \\
\hline & (1) & (2) & (3) & $(4)$ & $(5)$ & (6) \\
\hline$\Delta$ Employment $(\%)$ & $\begin{array}{c}1.252^{* * *} \\
(0.475)\end{array}$ & $\begin{array}{c}2.211^{* * *} \\
(0.254)\end{array}$ & $\begin{array}{l}-0.930 \\
(1.169)\end{array}$ & $\begin{array}{c}0.998^{* * *} \\
(0.173)\end{array}$ & $\begin{array}{c}2.089^{* *} \\
(0.973)\end{array}$ & $\begin{array}{c}0.647^{* * *} \\
(0.182)\end{array}$ \\
\hline Ind. Controls & & $\checkmark$ & & $\checkmark$ & & $\checkmark$ \\
\hline Region FE & & $\checkmark$ & & $\checkmark$ & & $\checkmark$ \\
\hline $\mathrm{N}$ & 509,039 & 412,906 & 506,912 & 445,337 & 538,327 & 470,730 \\
\hline Cluster & 265 & 265 & 264 & 264 & 264 & 264 \\
\hline 1st stage F-Test & 26.37 & 103.70 & 9.79 & 67.33 & 7.63 & 69.72 \\
\hline Mean DV & 44.98 & 45.43 & 61.15 & 60.99 & 54.84 & 54.88 \\
\hline
\end{tabular}

2SLS estimations using individual-level data. Image, Benefit and Membership are outcome variables based on Eurobarometer survey questions and are coded to lie between 0 and 100. Change in employment rate is computed over five years. Individual controls include age, gender and education dummies. Kleibergen-Paap rk Wald F statistic reported. Standard errors (clustered by region) in parentheses. *** $\mathrm{p}<0.01,{ }^{*} * \mathrm{p}<0.05,{ }^{*} \mathrm{p}<0.1$. 
Table A22: Effects of employment changes on turnout

\begin{tabular}{|c|c|c|c|c|c|}
\hline & $\begin{array}{c}\text { Turnout } \\
\text { OLS }\end{array}$ & $\begin{array}{c}\text { Turnout } \\
\text { OLS }\end{array}$ & $\begin{array}{l}(3) \\
\text { Turnout } \\
\text { OLS }\end{array}$ & $\begin{array}{c}(4) \\
\text { Turnout } \\
\text { 2SLS } \\
\text { (Bartik) }\end{array}$ & $\begin{array}{c}(5) \\
\text { Turnout } \\
\text { 2SLS } \\
\text { (Sectoral Shares) }\end{array}$ \\
\hline$\Delta$ Employment $(\%)$ & $\begin{array}{l}-0.1346 \\
(0.1495)\end{array}$ & $\begin{array}{c}0.1916^{* *} \\
(0.0786)\end{array}$ & $\begin{array}{c}0.2058^{* * *} \\
(0.0707)\end{array}$ & $\begin{array}{c}-2.9302^{* * *} \\
(1.1042)\end{array}$ & $\begin{array}{c}0.6091^{* * *} \\
(0.1164)\end{array}$ \\
\hline Year FE & & $\checkmark$ & $\checkmark$ & & $\checkmark$ \\
\hline Region FE & & $\checkmark$ & $\checkmark$ & $\checkmark$ & $\checkmark$ \\
\hline Country FE x Year & & & $\checkmark$ & & \\
\hline $\mathrm{N}$ & 704 & 704 & 704 & 691 & 704 \\
\hline F-Test & & & & 7.36 & 15.68 \\
\hline Cluster & 225 & 225 & 225 & 225 & 225 \\
\hline Mean DV & 46.85 & 46.85 & 46.85 & 46.54 & 46.85 \\
\hline
\end{tabular}

OLS and 2SLS estimations. Turnout (in \%) at European Parliament elections in 1994, 1999, 2004, 2009 and 2014. Change in employment rate is computed over five years. Kleibergen-Paap rk Wald F statistic reported. Standard errors (clustered by region) in parentheses. ${ }^{* * *} \mathrm{p}<0.01,{ }^{* *} \mathrm{p}<0.05$, $* \mathrm{p}<0.1$. 


\section{References}

Algan, Yann, Sergei Guriev, Elias Papaioannou, and Evgenia Passari, "The European Trust Crisis and the Rise of Populism," Brooking's Papers on Economic Activity, 2017.

Allport, Gordon W., The Nature of Prejudice, Reading, MA: Addison-Wesley, 1954.

Anderson, Christopher J., "The End of Economic Voting? Contingency Dilemmas and the Limits of Democratic Accountability," Annual Review of Political Science, 2007, 10 (1), 271296.

Angrist, Joshua D and Jörn-Steffen Pischke, Mostly Harmless Econometrics: An Empiricist's Companion, Princeton: Princeton University Press, 2008.

Autor, David, David Dorn, Gordon Hanson, and Kaveh Majlesi, "Importing Political Polarization? The Electoral Consequences of Rising Trade Exposure," 2016.

Autor, David H., David Dorn, and Gordon H. Hanson, "The China Syndrome: Local labor market impacts of import Competition in the United States," American Economic Review, 2013, 103 (6), 2121-2168.

Bakker, Ryan, Erica Edwards, Liesbeth Hooghe, Seth Jolly, Jelle Koedam, Filip Kostelka, Gary Marks, Jonathan Polk, Jan Rovny, Gijs Schumacher, Marco Steenbergen, Milda Vachudova, and Marko Zilovic, 1999-2014 Chapel Hill Expert Survey Trend File, Chapel Hill, NC: University of North Carolina, Chapel Hill, 2015.

Bartik, Timothy, "Boon or Boondoggle? The Debate over State and Local Economic Development Policies," W.E. Upjohn Institute for Employment Research, 1991, 1, 1-16.

Becker, Sascha O. and Thiemo Fetzer, "Does Migration Cause Extreme Voting?," Warwick Working Paper Series, 2016, (306).

_ , Peter H. Egger, and Maximilian von Ehrlich, "Going NUTS: The effect of EU Structural Funds on Regional Performance," Journal of Public Economics, 2010, 94 (9-10), 578-590.

_ , Thiemo Fetzer, and Dennis Novy, "Who Voted for Brexit? A Comprehensive DistrictLevel Analysis," Economic Policy, 2017, 32 (92), 601-650.

Blanchard, Olivier Jean and Lawrence Katz, "Regional Evolutions," Brookings Papers on Economic Activity, 1992, 23 (1), 1-76.

Boomgaarden, Hajo G., Andreas R. T. Schuck, Matthijs Elenbaas, and Claes H. de Vreese, "Mapping EU Attitudes: Conceptual and Empirical Dimensions of Euroscepticism and EU Support," European Union Politics, 2011, 12 (2), 241-266.

Borjas, George J., "The Labor Demand Curve is Downward Sloping: Reexamining the Impact of Immigration on the Labor Market," The Quarterly Journal of Economics, 2003, 118 (4), $1335-1374$. 
Bound, John and Harry J. Holzer, "Demand Shifts, Population Adjustments, and Labor Market Outcomes During the 1980s," Journal of Labor Economics, 2000, 18 (1), 20-54.

Braun, Daniela, Hermann Schmitt, Andreas Wuest, Sebastian Popa, Slava Mikhaylov, and Felix Dwinger, Euromanifestos Project (EMP) 1979 - 20092015.

Bruno, Giovanni, "Estimation and Inference in Dynamic Unbalanced Panel Data Models with a Small Number of Individuals," Stata Journal, 2005, (February), 473-500.

Card, David, "Immigrant Inflows, Native Outflows, and the Local Labor Market Impacts of Higher Immigration," Journal of Labor Economics, 2001, 19 (1), 22-64.

Che, Yi, Yi Lu, Justin R Pierce, and Peter K Schott, "Does Trade Liberalization with China Influence U.S. Elections?," NBER Working Paper Series, 2016, (22178).

Colantone, Italo and Piero Stanig, "The Trade Origins of Economic Nationalism: Import Competition and Voting Behavior in Western Europe," American Journal of Political Science, forthcoming, 2018.

De Master, Sara and Michael Le Roy, "Xenophobia and the European Union," Comparative Politics, 2000, 32 (4), 419-436.

Dippel, Christian, Robert Gold, and Stephan Heblich, "Globalization and Its (Dis)Content: Trade Shocks and Voting Behavior," NBER Working Paper, 2015, 21812.

Down, Ian and Carole J. Wilson, "A Rising Generation of Europeans? Life-cycle and Cohort Effects on Support for 'Europe'," European Journal of Political Research, 2013, 52 (4), 431-456.

Dustmann, Christian, Barry Eichengreen, Sebastian Otten, André Sapir, Guido Tabellini, and Gylfi Zoega, "Europe's Trust Deficit. Causes and Remedies," in "Monitoring International Integration," CEPR Press, 2017.

_, Francesca Gabbri, and Ian Preston, "The Impact of Immigration on the British Labor Market," The Eocnomic Journal, 2005, 115.

_, Tommaso Frattini, and Ian P. Preston, "The Effect of Immigration along the Distribution of Wages," Review of Economic Studies, 2013, 80 (1), 145-173.

Eurobarometer, "Eurobarometer Sampling and Fieldwork," Technical Report 2017.

European Commission, ., "Eurobarometer Data," 2017.

Fernandez, Juan J., Monika Eigmüller, and Stefanie Börner, "Domestic transnationalism and the formation of pro-European sentiments," European Union Politics, 2016, 17 (3), 457-481. 
Foster, Chase and Jeffry Frieden, "Crisis of Trust: Socio-economic Determinants of Europeans' Confidence in Government," European Union Politics, 2017, 18 (4), 511-535.

Frieden, Jeffry, "The Crisis, the Public, and the Future of European Integration," in Francesco Caselli, ed., After the Crisis: Reform, Recovery, and Growth in Europe, number May, Oxford University Press, 2016, pp. 1-45.

Garry, John and James Tilley, "The Macroeconomic Factors Conditioning the Impact of Identity on Attitudes towards the EU," European Union Politics, 2009, 10 (3), 361-379.

Golder, Matt, "Far Right Parties in Europe," Annual Review of Political Science, 2016, 19 (1), 477-497.

Goldsmith-Pinkham, Paul, Isaac Sorkin, and Henry Swift, "Bartik Instruments: What, When, Why, and How," 2017.

Gomez, Raul, "The Economy Strikes Back: Support for the EU during the Great Recession," Journal of Common Market Studies, 2015, 53 (3), 577-592.

Guiso, Luigi, Helios Herrera, Massimo Morelli, and Tommaso Sonno, "Demand and Supply of Populism," 2017.

Hernández, Enrique and Hanspeter Kriesi, "Turning your back on the EU. The role of Eurosceptic parties in the 2014 European Parliament elections," Electoral Studies, 2016, 44, $515-524$.

Hobolt, Sara B. and Catherine E. de Vries, "Public Support for European Integration," Annual Review of Political Science, 2016, 19 (1), 413-432.

IMF, "Tackling Inequality," in "Fiscal Monitor 2017" number October 2017.

Jaeger, David A, Joakim Ruist, and Jan Stuhler, "Shift-Share Instruments and the Impact of Immigration," 2017.

Judson, Ruth A. and Ann L. Owen, "Estimating Dynamic Panel Data Models: A Guide for Macroeconomists," Economics Letters, 1999, 65 (1), 9-15.

Katz, Lawrence and Kevin Murphy, "Changes in Relative Wages, 1963-1987: Supply and Demand Factors," The Quarterly Journal of Economics, 1992, 107 (1), 35-78.

Kuhn, Theresa, Erika Van Elsas, Armen Hakhverdian, and Wouter van der Brug, "An Ever Wider Gap in an Ever Closer Union: Rising Inequalities and Euroscepticism in 12 West European Democracies, 1975-2009," Socio-Economic Review, 2016, 14 (1), 27-45.

Lubbers, Marcel and Peer Scheepers, "Political versus Instrumental Euro-scepticism: Mapping Scepticism in European Countries and Regions," European Union Politics, 2005, 6 (2), 223-242. 
_ and _ , "Explanations of Political Euro-Scepticism At the Individual, Regional and National Levels," European Societies, 2007, 9 (4), 643-669.

_ and _, "Divergent Trends of Euroscepticism in Countries and Regions of the European Union," European Journal of Political Research, 2010, 49 (6), 787-817.

Lucassen, Geertje and Marcel Lubbers, "Who Fears What? Explaining Far-Right-Wing Preference in Europe by Distinguishing Perceived Cultural and Economic Ethnic Threats," Comparative Political Studies, 2012, 45 (5), 547-574.

NAS, The Economic and Fiscal Consequences of Immigration, Washington D.C.: The National Acadmey od Sciences Press, 2017.

Nickell, Stephen, "Biases in Dynamic Models with Fixed Effects," Econometrica, 1981, 49 (6), $1417-1426$.

Osterloh, Stefan, "Can Regional Transfers Buy Public Support? Evidence from EU Structural Policy," 2011.

Roth, Felix, Thomas Otter, and Felicitas Nowak-Lehmann, "Crisis and Trust in National and European Union Institutions: Panel Evidence for the EU, 1999 to 2012," EUI Working Paper RSCAS, 2013, 31, 1-37.

Schmidt, Vivien A., "Democracy and Legitimacy in the European Union Revisited: Input, Output and 'Throughput'," Political Studies, 2013, 61 (1), 2-22.

Serricchio, Fabio, Myrto Tsakatika, and Lucia Quaglia, "Euroscepticism and the Global Financial Crisis," Journal of Common Market Studies, 2013, 51 (1), 51-64. 